\title{
Drugability of Extracellular Targets: Discovery of Small Molecule Drugs Targeting Allosteric, Functional, and Subunit-Selective Sites on GPCRs and Ion Channels
}

\author{
Dimitri E Grigoriadis ${ }^{\star,}$, Samuel R J Hoare ${ }^{1}$, Sandra M Lechner ${ }^{1}$, Deborah H Slee ${ }^{1}$ and John A Williams ${ }^{1}$ \\ ${ }^{1}$ Neurocrine Biosciences Inc., San Diego, CA, USA
}

\begin{abstract}
Beginning with the discovery of the structure of deoxyribose nucleic acid in 1953, by James Watson and Francis Crick, the sequencing of the entire human genome some 50 years later, has begun to quantify the classes and types of proteins that may have relevance to human disease with the promise of rapidly identifying compounds that can modulate these proteins so as to have a beneficial and therapeutic outcome. This so called 'drugable space' involves a variety of membrane-bound proteins including the superfamily of G-protein-coupled receptors (GPCRs), ion channels, and transporters among others. The recent number of novel therapeutics targeting membrane-bound extracellular proteins that have reached the market in the past 20 years however pales in magnitude when compared, during the same timeframe, to the advancements made in the technologies available to aid in the discovery of these novel therapeutics. This review will consider select examples of extracellular drugable targets and focus on the GPCRs and ion channels highlighting the corticotropin releasing factor (CRF) type 1 and $\gamma$-aminobutyric acid receptors, and the Cav2.2 voltage-gated ion channel. These examples will elaborate current technological advancements in drug discovery and provide a prospective framework for future drug development.
\end{abstract}

Neuropsychopharmacology Reviews (2009) 34, 106-125; doi: I0. I038/npp.2008. I49; published online 17 September 2008

Keywords: allosteric regulation; CRF; drug discovery; ligand-gated; peptides; small molecule

\section{INTRODUCTION}

The term 'drugability' (or 'druggability') has not yet achieved mainstream status enough to warrant a definition in Webster's, however, for those in the fields of genetics and medicine in drug discovery, it is a term extremely well understood. Loosely, this term refers to the ability of a xenobiotic or small molecule to modulate the function of an endogenous protein and have a beneficial effect on the organism. More specifically, this term relates to drug discovery and the ability of modifying a disease state through a specific protein interaction or mechanism in the body. The methodologies for drug discovery have enjoyed a rapid evolution in a relatively short period time from the initial direct radioligandbinding experiments designed to test single molecular entities, to sophisticated technologies that allow large chemical libraries to be synthesized and tested on multiple targets simultaneously using high-throughput liquid handling and detection techniques. These advancements in technology,

${ }^{*}$ Correspondence: Dr DE Grigoriadis, Neurocrine Biosciences Inc., 12780 El Camino Real, San Diego, CA 92130, USA, Tel: +1858 617 7671, Fax: +1858 617 7696, E-mail: dgrigoriadis@neurocrine.com

Received 2 June 2008; revised 18 August 2008; accepted 18 August 2008 however, have not yet yielded that expected quantum leap in available therapeutics for unmet medical needs. Leaving aside for a moment the increasing hurdles of safety, development, and regulatory environments that all potential drugs face, the initial selection of a target, and the assessment of its drugability as a disease-relevant molecular mechanism is paramount in the discovery of novel therapeutics.

The sequencing of the human genome in 2001 by the International Human Genome Sequencing Consortium estimated in draft form, that the genome contains approximately 30000 genes (Lander et al, 2001; Venter et al, 2001). This collaboration later converted this draft to a final result reducing the initial number of gaps from $\sim 150000$ to 400 resulting in a refinement of the estimates to a genome containing between 20000 and 25000 genes (Consortium, 2004). Of these, estimates range from 10 to $15 \%$ of these genes that can generate drugable targets and only half of those may be truly related to proteins that are actually linked to disease (Hopkins and Groom, 2002). Of the myriad of proteins that are expressed on the surface of cells, some entirely specific to the type of cell in the body, two families lead the drugable universe. These two families are the G-protein-coupled receptors (GPCRs); proteins that are involved in transducing signals from the outside of the 
cell to the inside of the cell through endogenous ligands, and the ion channels; proteins that either through endogenous ligands or electrically evoked signals, modulate the membrane potential of cells by allowing the transport of ions through the extracellular membrane. On the basis of the information gained from the description of the human genome previously described, GPCRs represent the largest drugable target family (represented by 1000-2000 genes) and are currently the targets for $30-40 \%$ of the drugs on the market today (Hopkins and Groom, 2002). Ion channels appear to be represented by 400 genes in the human genome (Venter et al, 2001) and are currently the targets for approximately $7 \%$ of the current marketed drugs (Hopkins and Groom, 2002). Even with these impressive statistics, a significant portion of identified GPCRs and ion channels still remain to be characterized, and more importantly, their relevance to specific disease states elucidated. To complicate matters somewhat further, there is still a popular notion that within the human genome, there are a finite number of drugable targets specifically defined by these genes (one gene $=$ one target). However, the future prospects are much more sanguine when we explore some of the novel technological advances that are continually being developed.

The elucidation of multimeric proteins formed in response to disease, allosteric interactions of small molecules, cell-specific signaling mechanisms, and biased agonism (the selective activation of specific signaling pathways through the same receptor protein dependent on differential ligand/receptor interactions) all offer opportunities to evaluate the drugable space from different perspectives, in fact, increasing the number, scope and definition of 'drugable' targets beyond the one-gene-per-target approach. In a very recent example of biased agonism, Drake et al (2008) have shown, that selective ligands for the $\beta_{2^{-}}$ adrenergic receptor can cause differential intracellular signaling by stimulating $\beta$-arrestin-dependent receptor activities to a much greater extent than their given efficacy for G-protein activation leading to a potential for development of a novel class of receptor modulators. This paper will focus on the characteristics of two families of extracellular drugable targets, the GPCRs and ion channels, and illustrate some of the challenges and the methodologies and advancements used to overcome some of these challenges that have led to the successful discovery of small molecule therapeutics in disease; some currently in clinical trials.

\section{G-PROTEIN-COUPLED RECEPTORS}

\section{Drug Development Challenges for Newly Discovered G-Protein-Coupled Receptors}

Early drug discovery on GPCRs in central nervous system (CNS) diseases focused on small molecule receptors, typified by the monoamine receptors. These receptors were immediately tractable drug targets largely because their binding pockets have evolved to bind their small, drug-like endogenous ligands. These ligands, such as dopamine, norepinephrine or serotonin, provided ideal chemical starting points for drug development. With the application of molecular biology, the diversity of molecular targets in CNS diseases expanded enormously. Many of the newly discovered GPCR targets were quite different from the classical monoamine GPCRs, both in terms of the molecular structure of the receptors themselves and the size of the endogenous ligands that activate them. These two features presented a considerable challenge to developing drug-like molecules for the receptors. In this section, it will be shown how an understanding of the structural and mechanistic basis of receptor binding and activation has been applied to improve the 'drugability' of these targets resulting in the successful development of drug-like molecules.

\section{GPCR Structure and Function: Allosteric Modulation in Drug Development for Complex GPCRs}

GPCRs for small CNS ligands, such as the monoamines epinephrine and dopamine, are generally straightforward drug targets. These GPCRs are comprised of a single domain of seven membrane-spanning $\alpha$-helices that both binds the ligand and propagates the signal of G-protein activation (Ballesteros et al, 2001). The binding site has evolved to bind a small ligand, formed as a pocket within the cluster of $\alpha$-helices, and so is tractable for small molecule medicinal chemistry (Rasmussen et al, 2007). However, not all small CNS ligands bind simple GPCRs. The excitatory neurotransmitter glutamate and the inhibitory $\gamma$ aminobutyric acid (GABA), besides acting on ion channels to directly mediate neurotransmission, also modulate GPCRs in the CNS (Heresco-Levy, 2005; Niswender et al, 2005). These GPCRs present a considerable challenge to drug development owing to a complicated receptor structure. When the first glutamate GPCR was cloned in 1991 (Houamed et al, 1991; Masu et al, 1991), it was found to possess a strikingly different primary structure from the GPCRs cloned previously, revealing a new GPCR subfamily, termed the class C GPCRs. The predicted structure possessed seven membrane-spanning $\alpha$-helices, like all GPCR's, but the predicted N-terminal extracellular domain (ECD) was much larger (hundreds of amino-acid residues), raising the question of how the receptor bound glutamate and was activated. The second unusual feature of this GPCR family was revealed when the $G A B A_{B}$ receptor was cloned (Bettler et al, 2004). Previously, the $\mathrm{GABA}_{\mathrm{B}}$ receptor had been defined pharmacologically as the receptor for the antispastic drug baclofen. When initially cloned and expressed, the pharmacological profile of the cloned receptor did not fully recapitulate the expected activity of a $G A B A_{B}$ receptor and the signaling efficacy of the receptor was surprisingly low (Kaupmann et al, 1997). Subsequently, a number of groups demonstrated a surprising phenomenon. A second subtype of the receptor was identified and when the two receptors were coexpressed a fully functional 
$\mathrm{GABA}_{\mathrm{B}}$ receptor was finally demonstrated to be a dimer of the two subunits (Kaupmann et al, 1998; Ng et al, 1999; White et al, 1998). The dimer concept was also demonstrated for other members of the class $C$ family, such as the metabotropic glutamate receptors and the calcium-sensing receptor (Pin et al, 2005).

The unusually large extracellular region is comprised of a Venus fly-trap (VFT) domain, revealed by X-ray crystallography (Kunishima et al, 2000; Tsuchiya et al, 2002) that binds the endogenous ligand (glutamate or GABA). In an inactive state the lobes of this domain are separated in an open configuration (Figure 1a). In the active state of the VFT, promoted by binding of an endogenous ligand (Figure 1b), the lobes are brought together in a closed configuration (Kunishima et al, 2000; Pin et al, 2005; Tsuchiya et al, 2002). The VFT is also involved in dimer formation between the two subunits that comprise the receptor (Pin et al, 2005); a key feature in the basic understanding of the functional nature of this particular protein. The VFT is connected to the transmembrane

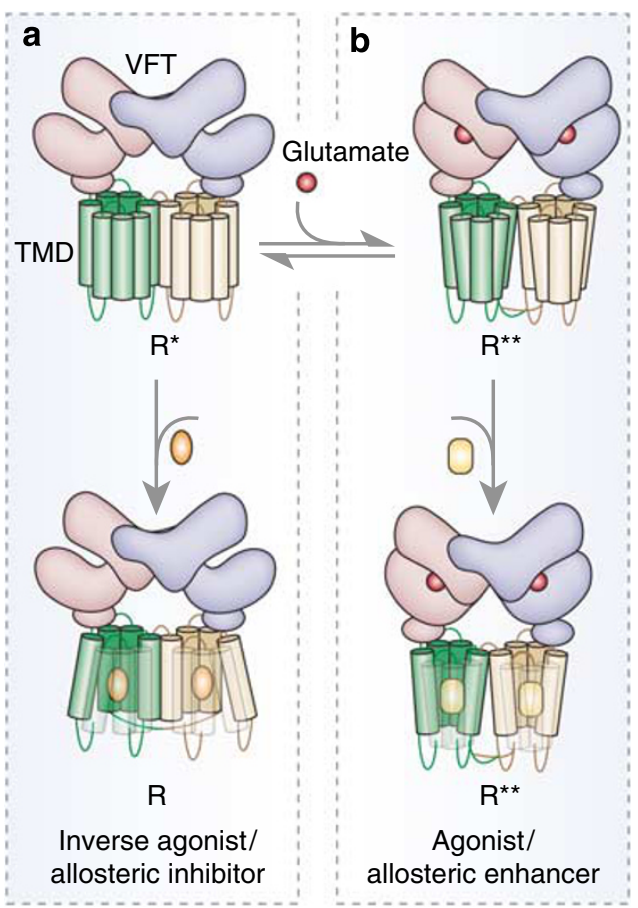

Figure 1. Diagrammatic representation of the domain structure of class C GPCRs. The receptor is comprised a dimer of subunits. Each subunit is divided into the bi-lobed Venus fly-trap (VFT) domain, which binds the endogenous ligand, connected to the transmembrane domain (TMD), which activates G-protein (Pin et al, 2005). The structure of the VFT has been solved (Kunishima et al, 2000; Tsuchiya et al, 2002). The TMD has been proposed to adopt multiple conformational states differing in their extent of activation (Pin et al, 2005), denoted here as the inactive state R, the partially active state $R^{\star}$, and the fully active state $R^{\star \star}$. Panel (a) shows that allosteric inhibitors bind the TMD and promote the inactive state $\mathrm{R}$, attenuating activation by the endogenous ligand. Panel (b) shows that allosteric enhancers bind the TMD and stabilize the fully active conformation $\mathrm{R}^{\star *}$ that enhances the activity of the endogenous ligand. More complex modes of allosteric regulation have also been demonstrated on class C GPCRs (Parmentier et al, 2002). domain (TMD) comprising the seven membrane-spanning $\alpha$-helices (Figure 1). The TMD, mediating G-protein activation, can exist in inactive and active conformations (Parmentier et al, 2002), with three predominant conformations being proposed - inactive, partially active, and fully active (Pin et al, 2005), designated here as $\mathrm{R}, \mathrm{R}^{\star}$, and $\mathrm{R}^{\star *}$, respectively (Figure 1). The conformation of the TMD is subsequently modulated by the VFT. This structure of class C GPCRs presented both a problem and an opportunity for drug development. The first apparent problem was simply a technical one for the $\mathrm{GABA}_{\mathrm{B}}$ receptor. The discovery and elucidation of $\mathrm{GABA}_{\mathrm{B}}$ receptor heterodimerization allowed the expression of a fully functional cloned receptor for use in drug discovery and development (Bettler et al, 2004). The availability of the cloned receptor allows pharmacological characterization of a specified molecular target, rather than an activity in a tissue. The structure of the cloned receptor can also be modified using the techniques of molecular biology to introduce specific amino-acid mutations allowing a detailed investigation of direct structure-function relationships that can aid compound SAR. This enabled modern drug discovery utilizing these cloned and expressed receptors in high-throughput in vitro testing, both for lead discovery through screening (HTS) and for lead optimization through focused medicinal chemistry. The second problem is that the structural organization of class C GPCRs is much more complex than the monoamine GPCRs; the ligand-binding site and G-protein activation region reside on different domains of the receptor and, in the case of the $\mathrm{GABA}_{\mathrm{B}}$ receptor, the heterodimer of two GPCR subunits is required for receptor function. The application of this new knowledge of receptor structure and function to aid drug discovery will be detailed below.

Allosteric modulation represents one potentially tractable approach for drug development on class C GPCRs. Allosteric modulators are compounds that bind sites on the receptor that are spatially distinct from the endogenous ligand-binding site (Birdsall et al, 1995; Christopoulos, 2002). Put simply, the multiplicity of functional domains of class C GPCRs provides multiple sites for drugs to target beyond a direct action on the endogenous ligand-binding cleft on the VFT. Furthermore the conformational regulation inherent in signal transduction by the endogenous ligand can be coopted in allosteric regulation by pharmacological agents (Niswender et al, 2005; Pin et al, 2005). The TMD has been exploited as a drugable allosteric site for class C GPCRs, especially metabotropic glutamate receptors (Rudd and McCauley, 2005). This domain is tractable for drug development presumably because the membranespanning $\alpha$-helices are arranged to form a pocket that can bind small molecules, like monoamine receptors. This idea is supported by the finding that the TMD expressed in isolation binds the small molecule ligands (Binet et al, 2004; Goudet et al, 2004). A variety of functional activities and allosteric mechanisms of these molecules have been identified (reviewed in detail in Parmentier et al, 2002). In the simplest mechanisms, compounds can bind the TMD 
and activate it (agonism, Figure 1b), or bind this domain and prevent it from signaling (inverse agonism, Figure 1a). Agonism results from the small molecule stabilizing and promoting the formation of an active state $\left(\mathrm{R}^{* *}\right)$ of this domain (Figure $1 \mathrm{~b}$ ), although the presence of the VFT might hinder this process (Binet et al, 2004; Goudet et al, 2004; Pin et al, 2005). Reciprocally, inverse agonism results from small molecule promoting an inactive state of the transmembrane (TM) region (R; Goudet et al, 2004; Figure 1a). These ligands can also modulate activity of the endogenous ligands. Stabilization of $\mathrm{R}$ by inverse agonists (allosteric inhibitor) blocks the signaling activity of endogenous ligand, and agonist stabilization of the $\mathrm{R}^{* *}$ state (allosteric enhancer) results in potentiation of signaling by endogenous ligand (Parmentier et al, 2002; Pin et al, 2005; Figure 1). More complex modes of allosteric regulation have also been identified. For example, GABA binds the VFT of the $\mathrm{GABA}_{\mathrm{B} 1}$ subunit, which in turn activates, in trans, the TMD of the $\mathrm{GABA}_{\mathrm{B} 2}$ subunit within the heterodimer (Pin et al, 2005). In addition, there is a functional interaction between the VFT and TMDs that can be modulated by a ligand. The presence of the VFT suppresses direct activation of the TMD by allosteric ligands, however, these ligands potentiate the activation of the TMD by the activated VFT. This type of modulation (silent allosteric enhancement) allows allosteric ligands to have little activity by themselves but to potentiate the activity of the endogenous ligand.

Overall, understanding the allosteric mechanism of action of class C GPCR modulators has been critical in evolving initial leads, identified from HTS (Johnson et al, 2003), through lead optimization medicinal chemistry efforts to compounds that are currently being tested clinically (Niswender et al, 2005). Examples of these compounds include cinacalcet (compound 1, Figure 4a), an allosteric enhancer of the calcium-sensing receptor used to treat hypercalcemia associated with renal failure (Harrington and Fotsch, 2007), LY487379 (compound 2, Figure 4a) and other allosteric enhancers of group II mGlu receptors developed as potential treatments for schizophrenia (Rudd and McCauley, 2005), and CGP7930 (compound 3, Figure 4a) along with other $\mathrm{GABA}_{\mathrm{B}}$ receptor potentiators for treating addiction (Adams and Lawrence, 2007). The structural complexity that has led us down the path of allosteric modulation may also provide therapeutic value. As discussed extensively elsewhere, allosteric modulation maintains the spatial and temporal limits of endogenous receptor activation; receptor activity is modulated only where and when the endogenous ligand is present (Birdsall et al, 1995; Christopoulos, 2002). In contrast, effective concentrations of direct-acting agonists stimulate the receptor wherever the agonist is located and throughout the duration of agonist exposure, potentially leading to overstimulation of the target receptor and overdose, receptor desensitization in the target tissue, or side effects in collateral tissues. Silent allosteric enhancement, an extreme example of this phenomenon that is not easily permissible with the more straightforward receptor organi- zation of a monoamine GPCR, is crucial for the safe activity of the marketed drug cinacalcet on the calcium-sensing receptor. This drug acts in concert with calcium ions to activate this receptor, potentiating the negative feedback loop of blood calcium regulation, preventing potentially fatal hypercalcemia in renal failure. As the drug does not activate the calcium-sensing receptor alone, it does not lower blood calcium to dangerous levels thus providing the beneficial effect with limited risk. Allosteric modulation may also aid development of compounds that target specific receptor subtypes that all bind the same endogenous ligand, especially for specific subtypes of the family of eight metabotropic glutamate receptors (Rudd and McCauley, 2005). The endogenous ligand-binding site must preserve some structural similarity through evolution of receptor subtypes to bind the same endogenous ligand (the glutamate-binding domain on the VFT of mGlu receptors) whereas no such evolutionary pressure exists to preserve the structure of novel drugable sites (such as the discrete areas within the TMD).

Allosteric modulation has also been exploited for another family of GPCR's, the class B GPCR family (Foord et al, 2002; Hoare, 2005). These receptors have been traditionally viewed as particularly difficult to target with small molecules because of two potential complications, the structure of the receptor (discussed here) and the nature of the ligand (moderately sized peptides of 30-40 aminoacid residues, see below; Hoare, 2005). From a therapeutic perspective, one of the most interesting class B GPCRs in the CNS is the corticotropin releasing factor (CRF) type 1 receptor. Central $\mathrm{CRF}_{1}$ receptors have been rationalized as a potential novel target for the treatment of mood disorders including depression and anxiety (Grigoriadis, 2005; Hauger et al, 2006; Holsboer, 2003). This proposal is based on the hypothesis that anxiety and depression are stressrelated disorders and the established role of CRF as a principal regulator of the stress axis: CRF is a 41 amino-acid peptide that acts by the pituitary to regulate the hypothalamic-pituitary axis and in the CNS to modulate behavioral responses to stress (Bale and Vale, 2004; Smagin and Dunn, 2000).

The structure and mechanism of class B GPCRs, such as the $\mathrm{CRF}_{1}$ receptor, is more complex than the simple monoamine receptors, although not as daunting as the complexity of class C GPCRs. The receptors comprise a TMD formed of seven membrane-spanning $\alpha$-helices, and a moderately sized ECD of about 100-160 amino-acid residues (Figures 2 and 3). Like class $C$ receptors, the ECD binds the endogenous ligand and the TMD activates Gprotein, but the binding mechanism is slightly different because the peptide ligands need to bind to both the ECD and the TMD of class B GPCRs (Hoare, 2005). According to this 'two-domain' model, elaborated in Figure $2 \mathrm{~b}$ for the $\mathrm{CRF}_{1}$ receptor, the $\mathrm{C}$-terminal portion of the peptide binds the ECD of the receptor (Grace et al, 2004; Perrin et al, 1998). This 'affinity-trap' interaction brings the N-terminal portion of the peptide into the vicinity of the TMD, 


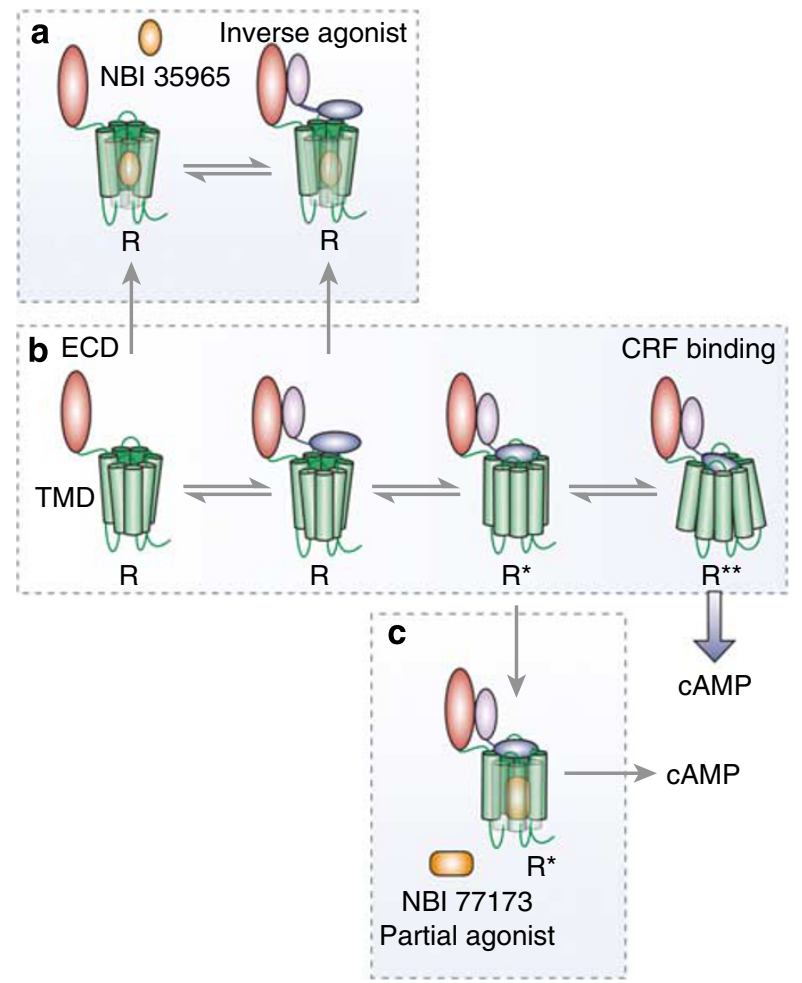

Figure 2. Schematic representation of $\mathrm{CRF}_{1}$ receptor activation by CRF and antagonism by small molecules. The CRF-binding mechanism is illustrated in panel (b). The C-terminal portion of CRF (purple) binds the Nterminal extracellular domain (ECD) of the receptor. This 'affinity-trap' interaction brings the $\mathrm{N}$-terminal region of the peptide (blue) into the vicinity of the transmembrane domain (TMD) of the receptor. Interaction of the N-terminal CRF portion with the TMD results in transition of the TMD from an inactive state $(R)$ to a weakly active state $\left(R^{\star}\right)$, and to a fully active state $\left(\mathrm{R}^{\star \star}\right)$. Panel (a) shows the mechanism of action of a standard $\mathrm{CRF}_{1}$ receptor antagonist, NBI 35965. This compound binds the TMD and locks it in the inactive state R. Once NBI 35965 is bound, CRF can still bind the ECD but CRF interaction with the TMD is inhibited because the receptor is stabilized in the inactive state $R$. Panel (c) shows the activity of the unusual $\mathrm{CRF}_{1}$ receptor weak partial agonist NBI 77173. This compound preferentially binds and stabilizes the weakly active state $R^{*}$. The model is built from data in Dautzenberg et al (1998), Grace et al (2004), Hauger et al (2006), Hoare et al (2003), (2004), (2008), Liaw et al (1997a, b), Mesleh et al (2007) and Perrin et al (1998).

facilitating this second interaction (Grace et al, 2004; Hauger et al, 2006; Hoare et al, 2004). Binding of the Nterminal peptide region to the TMD effects a conformational change to the protein that activates this receptor region, resulting in G-protein recruitment and subsequent intracellular signaling (Hoare et al, 2004; Nielsen et al, 2000). This activation process likely involves two distinct active conformations of the TMD (Figure 2b), the fully active state $R^{* *}$ that is the principle driver of G-protein activation, and a weakly active state $R^{*}$ that detectably signals only when the receptor is highly over expressed (Hoare et al, 2008). Interestingly, the two domains of the $\mathrm{CRF}_{1}$ receptor are functionally independent; peptide ligands bind isolated ECD fragments (Grace et al, 2004; Perrin et al, 1998), and are able to stimulate signaling through isolated TMD fragments (Hoare et al, 2004; Nielsen et al, 2000). This two-domain model has been elaborated in detail for other members of the class B GPCR family (reviewed in Hoare, 2005), although a partially different model has been proposed for the secretin receptor (Dong et al, 2006).

As was the case for the class C GPCRs, the complexity of class $\mathrm{B}$ receptor structure and mechanism provides an opportunity for the development of allosteric modulators, since more than one domain on the receptor can be targeted, and the endogenous ligand interaction involves conformational modulations than can be exploited by small molecules. Compounds that block CRF signaling on the $\mathrm{CRF}_{1}$ receptor in the CNS have been developed as potential treatments for depression and anxiety. The compounds were initially identified through HTS, were subsequently developed using medicinal chemistry (see below) and have since progressed into clinical trials (Binneman et al, 2008; Ising et al, 2007; Zobel et al, 2000). These compounds (see Figure 4e) are all allosteric modulators of the $\mathrm{CRF}_{1}$ receptor (Hoare et al, 2003). The binding determinants for the compounds are located centrally within the TMD (Figure 3; Hoare et al, 2006; Liaw et al, 1997a), spatially separated from the binding determinants for CRF, which are located in extracellular-proximal regions of the receptor (the extracellular face of the TMD and within the ECD, Figure 3, (Dautzenberg et al, 1998; Hauger et al, 2006; Hoare et al, 2006; Liaw et al, 1997a, b). Binding of standard chemotype small molecules within the TMD stabilizes the TMD in the inactive state $R$ (see Figure 2a), such that these compounds are classified as inverse agonists (Hoare et al, 2008). Stabilization of this inactive state inhibits binding of CRF to the TMD (Hoare et al, 2004; Nielsen et al, 2000). Consequently, the CRF-receptor interaction required to activate the receptor is blocked, so the compounds inhibit CRF signaling (Figure 2a). Interestingly, a structurally unusual small molecule NBI 77173 has been shown to block the $\mathrm{CRF}_{1}$ receptor through a different mechanism (Hoare et al, 2008). Instead of stabilizing the inactive state of the TMD, this compound stabilizes the weakly active state $\mathrm{R}^{\star}$ (Figure 2c). This difference is evidenced by NBI 77173 eliciting partial agonism rather than inverse agonism of a highly amplified cAMP response by a highly expressed receptor. This stabilization counteracts transition to the fully active state $\mathrm{R}^{* *}$ that would be stimulated by CRF, blocking transition to the receptor state that is the main driver of G-protein activation, resulting in antagonism of signaling (Figure 2c). Targeting an alternative conformation of the $\mathrm{CRF}_{1}$ receptor, such as the weakly active state instead of the inactive state, could facilitate the development of novel compounds with different chemical structure. Although these mechanisms have been elaborated in detail for the $\mathrm{CRF}_{1}$ receptor, it is not presently clear whether they are operational for other class B GPCRs. However, we have postulated that small molecules acting on other peptide class B GPCRs are likely to act in an allosteric manner (Hoare, 2007).

From a purely structural perspective, the molecular biology revolution revealed a broad diversity of GPCRs of 


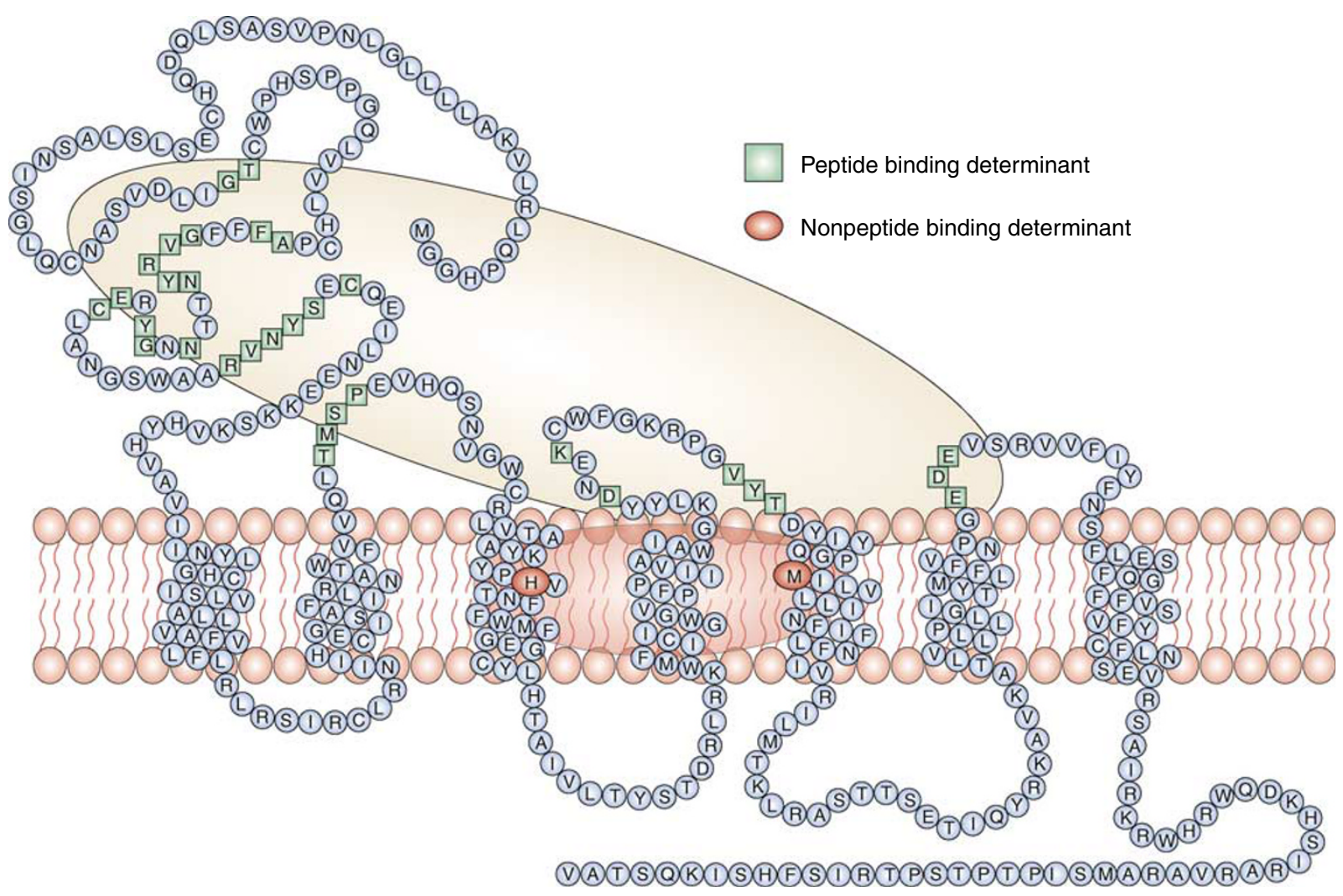

Figure 3. Location of peptide and small molecule-binding determinants on the $\mathrm{CRF}_{1}$ receptor. See Refs. Dautzenberg et al (1998), Hauger et al (2006), Liaw et al (1997a, b) for details.

potential value as novel targets for the treatment of multiple diseases. Beyond the simple structural and functional organization of monoamine class A GPCRs, these receptors presented a considerable challenge for small molecule drug development. Allosteric modulation has proven to be a viable and tractable route to the development of small molecule compounds for these receptors, some of which are currently progressing through clinical evaluation.

\section{Ligand Structure: Drug Development for Peptide GPCRs}

To develop a drug for a target of interest, it is first necessary to have in hand a chemical starting point. In the infancy of medicinal chemistry, endogenous organic compounds such as the neurotransmitters norepinephrine and histamine provided the initial chemical starting points. With the explosion of potential new targets to treat CNS diseases came the problem of identifying novel chemical starting points - many of the interesting GPCR targets were activated by endogenous peptide neuromodulators. Peptides themselves are generally considered poor chemical starting points for CNS diseases because they do not readily cross the blood-brain barrier. For drug discovery in general, peptides present challenges in terms of route of administration (usually injection), stability in the body and ease of synthesis and large-scale production. Consequently new methods were required to identify chemical starting points for the large majority of peptide-activated GPCRs. HTS has been an invaluable technological advancement in identifying chemical starting points for peptide GPCRs. Here we review the scientific processes involved in successfully applying HTS and in developing lead compounds from initial screening hits.

The first example of a successful HTS application illustrates how an initial weak hit was optimized using medicinal chemistry to yield valuable drug-like small molecules. As introduced above, blocking the $\mathrm{CRF}_{1}$ receptor is a potentially attractive novel mechanism for treating anxiety, depression and other stress-related disorders. However, the peptide CRF itself is not a viable starting point for medicinal chemistry because of its size (41 amino acids) and because its bioactive conformation (an extended $\alpha$-helix (Grace et al, 2007; Mesleh et al, 2007)) is not easily amenable to structural mimicry with a small molecule. In addition the target receptors for depression and anxietyrelated disorders are localized in the CNS, thus requiring a brain-penetrating pharmacological agent that will inevitably be used in a chronic manner. This precludes the use of many inconvenient routes of administration such as injectables, suppositories, or inhalants, requiring an orally bioavailable drug. Such requirements and constraints can 


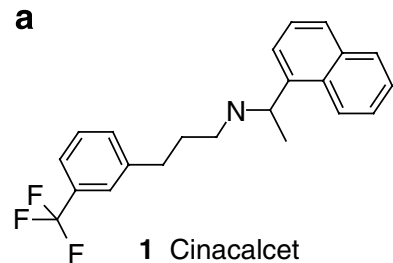<smiles>[Y16][AsH3]</smiles><smiles>CC(C)(CO)Cc1cc(C(C)(C)C)c(O)c(C(C)(C)C)c1</smiles><smiles>[R]c1ccc(N(C)c2nc(C)cc(C)n2)c(Br)c1</smiles>

$4 \quad \mathrm{R}=\mathrm{H} \quad K_{\mathrm{i}}=5,700 \mathrm{nM}$

$5 \quad \mathrm{R}=\mathrm{Me} \quad K_{\mathrm{i}}=1,100 \mathrm{nM}$

$6 \mathrm{R}=i-\operatorname{Pr} K_{\mathrm{i}}=96 \mathrm{nM}$<smiles>CCN(c1nc(C)cc(C)n1)c1ccc(C(C)C)cc1Br</smiles><smiles>CCN(CC)c1nc(C)cc(C)c1OC</smiles><smiles>COc1cc(Br)c(-n2ccc3c(C)cc(C)nc32)c(OC)c1</smiles>

$7 K_{\mathrm{i}}=46 \mathrm{nM}$

$8 K_{\mathrm{i}}=12 \mathrm{nM}$

$9 K_{\mathrm{i}}=1 \mathrm{nM}$

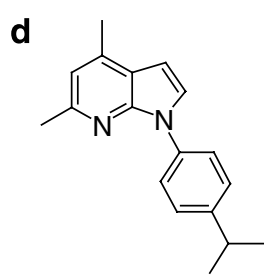

$10 K_{\mathrm{i}}=2,500 \mathrm{nM}$<smiles>Cc1cc(C)c2ccn(-c3ccc(C(C)C)cc3Br)c2n1</smiles>

$11 K_{\mathrm{i}}=47 \mathrm{nM}$<smiles></smiles>

12 Antalarmin<smiles>CCCN(CCC)c1cc(C)nc2c(-c3cnc(N(C)C)cc3C)c(C)nn12</smiles>

13 NBI 30775 /R121919<smiles>CC[C@H](C)Nc1nc(C)nc2c(-c3ccc(OC)nc3C)c(C)nn12</smiles>

14 Pexacerfont<smiles>CCC(CC)Oc1cc(C)nc(Oc2c(C)cc(C)cc2C)c1C</smiles>

15 CP 316,311

Figure 4. Small molecule modulators for class B and class C GPCRs. (a) Chemical structure of allosteric modulators of class C GPCRs. (b-e) Lead optimization for CRF receptor antagonists. (b) Lower aromatic substitutions in early CRF $_{1}$ receptor lead exploration (Arvanitis et al, 1999). (c) Ethyl substituent on central nitrogen and dihedral angle exploration in early lead exploration (Arvanitis et al, 1999). The position of the dihedral angle measured for compound $\mathbf{8}$ is indicated with the red-colored bonds (Hodge et al, 1999). This angle is constrained by the bicyclic core in compound $\mathbf{9}$. (d) Twoposition substituent on lower aromatic required for high affinity binding, suggesting the lower aromatic is held orthogonal to the plane of the core in the bioactive conformation (Hodge et al, 1999). (e) Lead CRF receptor antagonists: 12 —Antalarmin (Webster et al, 1996); 13 - NBI 30775/R121919 (Chen et al, 2004b); 14-Pexacerfont; 15—CP-316,311 (Binneman et al, 2008).

be satisfied with a small molecule compound, but this development path requires a viable chemical starting point. In the case of the $\mathrm{CRF}_{1}$ receptor, HTS was used to identify such a starting point.

An initial hit on the $\mathrm{CRF}_{1}$ receptor was reported in 1999 (compound 4, Figure 4b), identified from screening the DuPont chemical library in competition against ${ }^{125} \mathrm{I}-\mathrm{CRF}$ binding to the endogenous $\mathrm{CRF}_{1}$ receptor in rat brain homogenates (Arvanitis et al, 1999). (First detailed report of small molecule development for the $\mathrm{CRF}_{1}$ receptor, from screening hit to lead molecules.) This compound weakly bound the receptor $\left(K_{\mathrm{i}}\right.$ of $\left.5.7 \mu \mathrm{M}\right)$ and was shown to act as an antagonist, blocking CRF-stimulated signaling in the rat brain tissue $\left(\mathrm{IC}_{50}\right.$ of $\left.20 \mu \mathrm{M}\right)$. After identifying this initial hit, 
the next step down this drug development path was optimizing the hit into a bona fide lead. The first efforts focused on improving the affinity, to maximize the chances of showing efficacy at reasonable levels of compound exposure in experimental animals. The introduction of a simple methyl group at the four-position of the phenyl ring (compound 5, Figure $4 \mathrm{~b}$ ) improved the affinity approximately fivefold $\left(K_{\mathrm{i}}\right.$ of $\left.1.1 \mu \mathrm{M}\right)$. Increasing the size of the 4-methyl group led to the 4-i-propyl analog 6 (Figure $4 \mathrm{~b}$ ) with an additional 11-fold improvement in $\mathrm{CRF}_{1}$ receptorbinding affinity $\left(K_{\mathrm{i}}\right.$ of $\left.96 \mathrm{nM}\right)$. The introduction of a single additional methylene unit (which resulted in a simple ethyl substituent on the linking nitrogen atom at the two-position of the pyrimidine) modestly increased the affinity further (7, $K_{\mathrm{i}}$ of $46 \mathrm{nM}$, Figure $4 \mathrm{c}$ ). Finally, modifying the two- and four-position substituents on the phenyl ring yielded high affinity antagonists exemplified by compound 8 ( $K_{\mathrm{i}}$ of $12 \mathrm{nM}$, Figure 4c). Nuclear magnetic resonance and X-ray analysis of this monocyclic antagonist had shown that the dihedral angle $\phi$ between the central core nitrogen and the pyrimidine group was almost equal to $0^{\circ}$ (compound 8 , Figure 4c; Hodge et al, 1999). Subsequently it was demonstrated that conformationally locking the compound to maintain this dihedral angle with the use of a bicyclic core yielded very potent molecules (compound $9, K_{\mathrm{i}}$ of $1 \mathrm{nM}$, Figure 4c; Hodge et al, 1999).

The relative orientation of the phenyl group and the planar core heterocycle was also examined. Potentially free rotation of the phenyl group, as in compound 10, (Figure 4d), resulted in low affinity for the $\mathrm{CRF}_{1}$ receptor ( $K_{\mathrm{i}}$ of $2.5 \mu \mathrm{M}$, (Hodge et al, 1999). Two-position substituents likely impose steric constrains that result in the phenyl ring lying orthogonal to the plane of the core (Kehne and De Lombaert, 2002). This is likely the preferred configuration for bioactivity because the two-position substituents dramatically increase $\mathrm{CRF}_{1}$ receptor affinity (compound $11, K_{\mathrm{i}}$ of $47 \mathrm{nM}$, Figure $4 \mathrm{~d}$ ). The final area of SAR exploration has been the 'top' alkyl group, a simple methyl in the initial lead optimization efforts, expanded to lipophilic alkyl chains in early lead optimization (eg antalarmin, compound 12, Figure 4e). Similar chemotypes were also reported at this time, including antalarmin and CP-154,526 (Chen et al, 1996; Schulz et al, 1996). After optimizing for affinity, further drug development efforts have focused on improving the physicochemical characteristics of the molecules themselves to improve pharmacokinetics, typically by reducing lipophilicity using heteroatoms, potentially also increasing basicity (reviewed in Tellew and Luo 2008). These efforts yielded compounds that have entered clinical trials, such as NBI 30775/R121919 (compound 13, Figure 4e; Chen et al, 2004b), Pexacerfont (compound 14, Figure 4e) and CP-316311 (compound 15, Figure 4e). Although Pfizer has just recently published that CP-316,311 failed in a major depression clinical trial (Binneman et al, 2008), Pexacerfont from Bristol-Myers Squibb has currently completed three independent phase II/
III clinical trials for the potential treatment of generalized anxiety disorder (Clinicaltrials.gov identifier number NCT00481325), major depressive disorder (Clinicaltrials. gov identifier number NCT00135421), and irritable bowel syndrome (Clinicaltrials.gov identifier number NCT00399438). In addition, GlaxoSmithKline (GSK) has recently reported that 876008 , a selective $\mathrm{CRF}_{1}$ receptor antagonist, failed to reach statistically significant differences in the key efficacy endpoints between 876008 and placebo at 12 weeks in a Phase II clinical trial for social anxiety disorder (Clinical trials.gov identifier number NCT00397722). However, a second selective $\mathrm{CRF}_{1}$ receptor antagonist (561679) has very recently begun a Phase II clinical trial in major depressive disorder (Clinical trials.gov identifier number NCT00733980).

In the modern era HTS remains to an extent an exercise in serendipity, inasmuch as success requires that the chemical space of the library being screened intersects with that of an active chemical structure on the target-in essence the union of the drugability of the target and the drug-likeness of the small molecule. Indeed the identification of the initial lead for the $\mathrm{CRF}_{1}$ receptor was almost entirely serendipitous. For other GPCRs the chance element has been reduced as much as possible by biasing the chemical space being screened using a priori assumptions regarding the types of chemical structures that are likely to interact with the target in the required manner. The structure of the receptor and the ligand has proved useful in this process. For example, activation of melanocortin 4 (MC4) receptors in the hypothalamus has been proposed as a potential means to exert central control over energy balance and food intake in treating obesity and other metabolic disorders. The amino-acid sequence of the MC4 receptor shares considerable homology with that of other GPCRs for which drugs had already been identified, such as the ghrelin receptor, which binds growth-hormone secretagogue compounds (Bondensgaard et al, 2004). A directed screen of a library containing growth-hormone secretagogue compounds yielded a moderate potency $(110 \mathrm{nM}) \mathrm{MC} 4$ receptor hit (Sebhat et al, 2002). Compounds elaborated from this initial lead are similar to the bioactive structure of the endogenous peptide agonist $\alpha$-melanocyte-stimulating hormone and synthetic peptide analogues (Sebhat et al, 2002; Sun et al, 2004). This information was used to guide further medicinal chemistry efforts to optimize small molecule potency for the MC4 receptor. Additional optimization provided selectivity for the MC4 receptor over the other four MC receptor subtypes, and the appropriate physicochemical profile to allow in vivo efficacy in disease models to be demonstrated (reviewed in Chen et al, 2004a; Todorovic and Haskell-Luevano, 2005).

It is important to bear in mind that the level of understanding of how these molecules function is still being enhanced. There are many examples of drug discovery efforts that have failed despite the 'similarity' of the target GPCRs to others in the same family. These targets 
at this time are apparently not drugable but clearly, with technologies evolving, further elucidation of the mechanisms involved, specific functional conformations and possible auxiliary protein requirements all may offer insights into our abilities to identify small molecules that have the potential of becoming novel therapeutics for diseases that can be affected by these targets.

\section{MEMBRANE-BOUND ION CHANNELS}

\section{Drug Development Challenges in Targeting Modulation of Ion Channel Function}

Ion channels represent a diverse group of integral membrane proteins that regulate the passage of ions across cell membranes. They are ubiquitously expressed throughout the body and critically involved in basic physiological processes such as regulation of membrane potential, signal transduction, secretory function, and cellular plasticity. These features, on the one hand, make them compelling drug targets and on the other, limit their drugability. This is particularly true when aiming to develop orally bioavailable CNS therapeutics, as essential peripheral processes are also highly regulated by ion channel function.

Classification of ion channels can be made using various methods. Although ion channels are specific for certain ions (sodium $\left(\mathrm{Na}^{+}\right)$, potassium $\left(\mathrm{K}^{+}\right)$, calcium $\left(\mathrm{Ca}^{2+}\right)$, chloride $\left(\mathrm{Cl}^{-}\right)$) or for classes of ions (cations or anions), they have most successfully been organized by how they are regulated. Ion channels transition between open and closed states by a complex process called 'gating', whereby a conformational change takes place allowing for or blocking the passage of ions through the channel pore. If the probability a channel will be in a particular state is regulated by membrane potential, the channel is termed 'voltage-gated'. Nearly all cells have some voltage-sensitive ionic permeability and these channels can be further classified by the kinetics of their gating. In addition to the complex processes by which channels gate, their structural organization provides another level of complexity when pursuing the development of drug-like molecules. If the probability a channel will be in a particular state is regulated by a chemical agent (ligand), the channel is termed 'ligand-gated'. Like GPCRs, ligandgated channels rely on the binding of a ligand to a specific receptor, although in this case the receptor is specifically located on the channel, and this interaction induces the conformational change necessary to open or close the channel. Ligand-gated channels often contain binding sites for multiple ligands that can each differentially regulate channel function either alone or in concert with other ligands. In this section, it will be shown how an understanding of the structural components, as well as the gating mechanisms regulating ion channel function has been applied to successfully develop drug-like molecules for ion channels.

\section{Voltage-Gated lon Channels: Novel Approaches to Modulation of $\mathrm{Ca}_{\mathrm{v}} 2.2$ in Drug Development}

Most voltage-gated calcium channels are multisubunit complexes (Catterall, 2000; Yu et al, 2005; Zhorov and Tikhonov, 2004; Figure 5), containing a principal poreforming subunit $(\alpha 1)$, which determines the permeation properties of the channel. This subunit also contains the binding site for most commercially available pharmaceuticals known to interact with calcium channels, as well as the voltage sensor, which regulates gating. The ten $\alpha_{1}$ subunits are divided into three families based on the voltage required for their activation (Bean, 1989). L-type calcium channels $\left(\mathrm{Ca}_{\mathrm{V}} 1.1-1.4\right)$, signified by $\alpha_{1 \mathrm{C}}, \alpha_{1 \mathrm{D}}, \alpha_{1 \mathrm{~F}}, \alpha_{1 \mathrm{~S}}, \mathrm{P}$ - and Q-type calcium channels $\left(\mathrm{Ca}_{V} 2.1\right)$, signified by $\alpha_{1 \mathrm{~A}}$, N-type calcium channels $\left(\mathrm{Ca}_{\mathrm{V}} 2.2\right)$, signified by $\alpha_{1 \mathrm{~B}}$, and R-type calcium channels $\left(\mathrm{Ca}_{\mathrm{V}} 2.3\right)$, signified by $\alpha_{1 \mathrm{E}}$, are all activated by high voltage (potentials greater than $-40 \mathrm{mV}$ ). T-type calcium channels $\left(\mathrm{Ca}_{\mathrm{V}} 3.1-3.3\right)$, signified by $\alpha_{1 \mathrm{G}}, \alpha_{1 \mathrm{H}}, \alpha_{1 \mathrm{I}}$, are activated by low voltage (more negative potentials). The $\alpha_{1}$

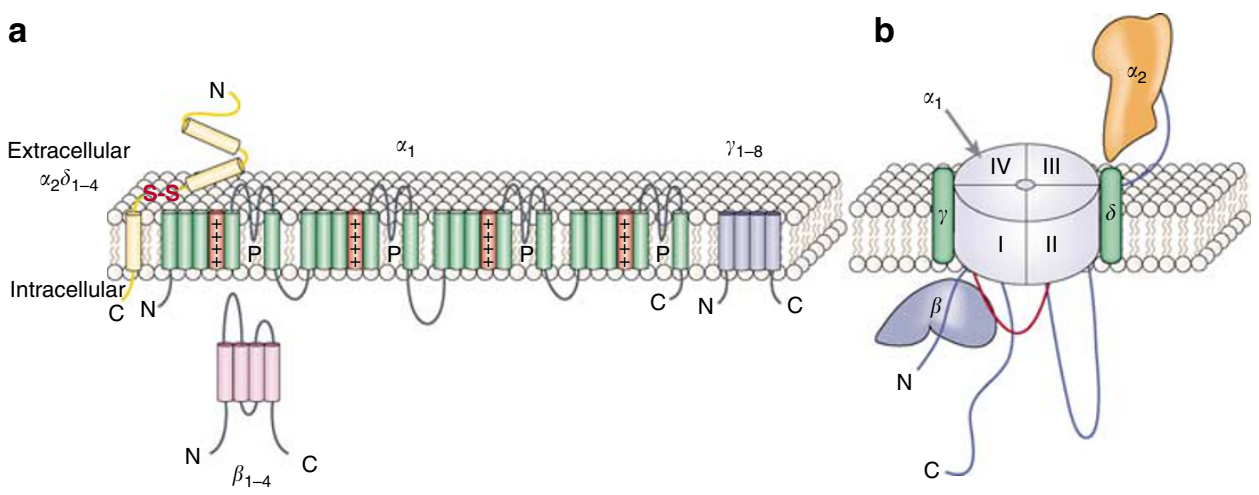

Figure 5. Schematic of a voltage-gated calcium channel. (a) Proposed membrane topology and structural domains of calcium channel subunits. Four homologous domains (I-IV), each with six transmembrane segments, comprise the pore-forming $\alpha_{1}$ subunit. The extracellular $\alpha_{2}$ subunit is disulfide linked to the transmembrane $\delta$-subunit, although these subunits arise from a single gene product that is posttranslationally cleaved. The $\beta$-subunit resides intracellularly and interacts with the loop connecting domain I to II. The $\gamma$-subunit has four transmembrane segments. (b) Vertical cross section showing the quadrameric arrangement of homologous domains to create the pore-forming $\alpha_{1}$ subunit, the central calcium permeable channel and its proposed relationship to the auxiliary subunits, $\alpha_{2} \delta$ and $\beta$. 
subunit has four homologous domains (I-IV), each comprised six $\alpha$-helical TM spanning segments (S1-S6), with a membrane-reentrant loop (P-loop) between S5 and S6 (Yang et al, 1993). This region (S5, S6, P-loop) comprises the ion-conducting pore and the selectivity filter. A combination of biophysical, mutagenesis and structural studies of the voltage-gated sodium and potassium channels has provided evidence for localization of the voltage-sensor regions on S4, which contains a pattern of positively charged amino acids critical to the gating mechanism (Bezanilla, 2002). The majority of therapeutically relevant ion channel drugs bind to the $\alpha_{1}$ subunit and inhibit ion flow, either by blocking the pore directly or by interfering with the gating mechanism. Fewer marketed drugs exist, which act to enhance ion flow through the channel by interacting with this subunit.

In addition to the principal pore-forming subunit $\left(\alpha_{1}\right)$, voltage-gated calcium channels are associated with auxiliary subunits (Figure 5) that modify their expression, functional properties, and subcellular localization. These include $\alpha_{2}, \beta$, $\gamma$, and $\delta$ (Arikkath and Campbell, 2003). $\alpha_{2}$ and $\delta$ are encoded by the same gene, which is posttranslationally cleaved to form the subunit $\alpha_{2} \delta$, of which there are four types, exhibiting tissue-specific localization. $\alpha_{2}$, localized extracellularly and involved in regulation of $\alpha_{1}$ function, is disulfide linked to $\delta$, which has a TM segment involved in anchoring the subunit to the membrane (Wiser et al, 1996). There are also four $\beta$-subunits, comprised four $\alpha$-helical segments that are localized intracellularly and regulate cell surface expression, as well as modulation of gating. They are involved in such functions as causing enhanced activation upon depolarization and altered rate and voltage dependence of inactivation. The $\beta$-subunits interact with the intracellular loop between domains I and II of the $\alpha_{1}$ subunit (Dolphin, 2003). There are eight $\gamma$-subunits, each containing four TM segments, which are involved in assembly and cell surface expression of not only voltagegated calcium channels, but potentially other receptors and membrane signaling proteins (Kang et al, 2001). There are only a few examples of therapeutically relevant ion channel drugs that bind to auxiliary subunits, however this approach has more recently gained increasing attention with the clinical and commercial success of gabapentin (Neurontin ${ }^{\circledR}$ ) and pregabalin (Lyrica ${ }^{\circledR}$ ).

$\mathrm{N}$-type calcium channels $\left(\mathrm{Ca}_{\mathrm{V}} 2.2\right)$ have been of particular interest in CNS drug discovery because of their almost exclusive localization to neurons, most particularly to presynaptic terminals, where they are involved in regulating the release of neurotransmitters by allowing an influx of calcium necessary for exocytotic vesicle fusion (Bertolino and Llinas, 1992; Dunlap et al, 1995). The discovery that these channels are also involved in transmission of nociceptive information in the spinal cord, coupled with the increase in expression of both the $\alpha_{1 \mathrm{~B}}$ and $\alpha_{2} \delta$ subunits in dorsal root ganglion neurons following nerve injury, led to an increased interest in targeting this channel for the development of pain therapies (Cizkova et al, 2002; Heinke et al, 2004; Luo et al, 2002; Westenbroek et al, 1998). In addition, 20-30 amino-acid peptide $\omega$-conotoxins from marine cone snails (GVIA from Conus geographus, MVIIA, from Conus magus, CVID from Conus catus; Ellinor et al, 1994; Olivera et al, 1994) have been shown to bind with high affinity (nM) and selectivity to $\mathrm{Ca}_{\mathrm{V}} 2.2$ and reduce measures of neurotransmission and pain response in behavioral models of nerve injury and inflammation, when administered into the spinal cord. The toxins bind to the $\alpha_{1 \mathrm{~B}}$ subunit in the P-loop region of the channel pore and potently block the channel directly (Feng et al, 2003).

A critical advance was made when Elan Pharmaceuticals developed a synthetic version of $\omega$-conotoxin MVIIA, referred to as ziconotide or SNX-111 (see Figure 6a for peptide sequence and refer to http://www.3dchem.com/

a

Cys-Lys-Gly-Lys-Gly-Ala-Lys-Cys-Ser-Arg-Leu-Met-Tyr-Asp-Cys-Cys-Thr-Gly-Ser-Cys-Arg-Ser-Gly-Lys-Cys-amide

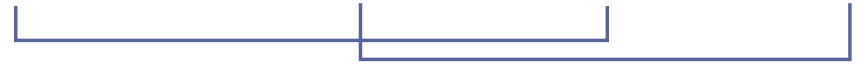

b
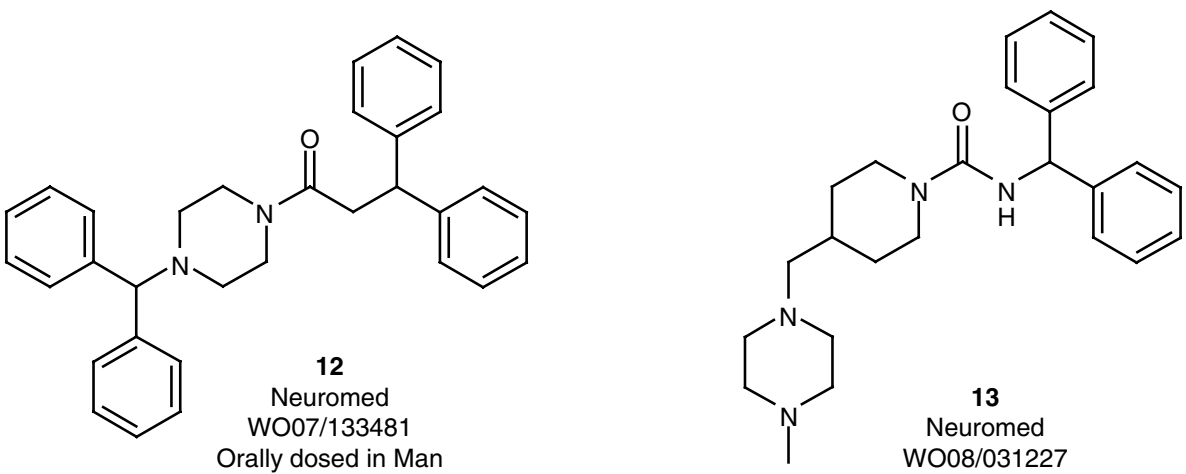

Figure 6. (a) Peptide sequence of ziconotide (also refer to http://www.3dchem.com/molecules.asp?ID =260 for the 3-D structure. (b) Examples of Cav2.2 antagonists from Neuromed. 
molecules.asp? ID $=260$ for the $3-\mathrm{D}$ structure of this peptide), which similarly binds $\alpha_{1 \text { в }}$ and blocks the channel directly (Bowersox et al, 1996; Wang et al, 2000). Ziconotide was the first selective N-type calcium channel blocker to be tested in clinical trials and has recently been approved for the treatment of severe chronic pain associated with cancer, AIDS and neuropathies, under the trade name Prialt ${ }^{\circledR}$ (Atanassoff et al, 2000; Brose et al, 1997; McGivern, 2007; Miljanich, 2004; Staats et al, 2004). Although Prialt does not induce tolerance and shows efficacy in patients refractory to opioid therapies, it is not without limitations. In addition to requiring intrathecal administration, Prialt induces significant orthostatic hypotension, most likely because of interaction with $\mathrm{Ca}_{\mathrm{V}} 2.2$ on neurons regulating blood pressure. Systemic administration inhibits sympathetic control of multiple cardiovascular functions regulated by peripheral $\mathrm{Ca}_{\mathrm{V}} 2.2$ (Penn and Paice, 2000).

Despite the known limitations of Prialt, its potent efficacy as a pain therapeutic has compelled many companies to engage in the development of small molecule antagonists of $\mathrm{Ca}_{\mathrm{V}} 2.2$ (Birch et al, 2004; Markman and Dworkin, 2006; McGivern, 2006; Sabido-David et al, 2004; Schroeder et al, 2006; Yogeeswari et al, 2007). The hope is that a small molecule would be orally bioavailable, be selective versus other channels and have an improved safety profile over Prialt. To date only one company, Neuromed, has successfully advanced a small molecule $\mathrm{N}$-type calcium channel blocker into clinical trials (NMED-160). Like ziconotide and the $\omega$-conotoxins, NMED-160 binds to the $\alpha_{1 \mathrm{~B}}$ subunit. However, unlike these peptides, it preferentially binds to the subunit in a frequency- or use-dependent manner (Snutch, 2003). Use dependence is a phenomenon whereby a higher frequency of action potentials results in a higher degree of channel block. Inhibition increases as channels are 'used' (for reviews of potential mechanisms by which inhibitors can take advantage of changes in gating and permeation processes, see Birch et al, 2004; Winquist et al, 2005). In vivo electrophysiological recordings have demonstrated an increased frequency of firing in nociceptive neurons of animals experiencing neuropathic pain. It is thought that targeting channels in this state would provide a degree of selectivity that would potently block $\mathrm{Ca}_{\mathrm{V}} 2.2$ channels involved in mediation of pain responses whereas sparing the role these channels play in normal central and peripheral sympathetic functions.

NMED-160 is a potent use-dependent blocker of $\mathrm{Ca}_{\mathrm{V}} 2.2$. Electrophysiological patch-clamp data in HEK cells expressing $\mathrm{Ca}_{\mathrm{V}} 2.2$ showed a more potent block of channel function at higher frequencies of stimulation $\left(\mathrm{IC}_{50}\right.$ of $120 \mathrm{nM}$ at $0.03 \mathrm{~Hz}$ compared to $50 \mathrm{nM}$ at $0.2 \mathrm{~Hz}$ ), with some selectivity over P- and Q-type calcium channels (1.6-fold) and L-type calcium channels (8-fold). NMED-160 has been shown to be orally efficacious in animal models of neuropathic pain and to be without serious side effects, including effects on cardiovascular end points, in phase I clinical trials. Although the chemical structure of NMED-160 has not been publically disclosed, a recently published Neuromed patent (WO 2007133481; Snutch and Fisher, 2007) discloses the structure of compound $\mathbf{1 6}$ (Figure $6 \mathrm{~b}$ ) for which human bioavailability data is presented. Merck \& Co, under license from Neuromed, was developing NMED-160 for the potential treatment of chronic pain. By March 2006, the drug was in phase II trials, however, as defined in their press release on August 8th, 2007, Neuromed and Merck discontinued development of this drug stating 'that MK6721 (also known as NMED-160) does not demonstrate the ideal pharmaceutical characteristics considered necessary to advance the compound further in development.' (please refer to the original press release for details at http:// www.neuromed.com/news/pressr.php?nr = 7\&txt = \&pyear $=$ 2007). The collaboration between Merck and Neuromed has continued toward identifying a compound with improved characteristics and several new patents have emerged (eg see compound 17, Figure 6b; Pajouhesh et al, 2008). A number of other companies are also active in this area (see compounds 18-21, Figure 7), although to date, no compounds from these efforts have yet been advanced into clinical trials.

As mentioned above, the majority of ion channel therapeutics have interactions with the pore-forming subunit, $\alpha_{1}$. In the case of $\mathrm{Ca}_{\mathrm{V}} 2.2$, this approach has been successful for ziconotide and progress has been made with newer compounds targeting a more specialized interaction with this subunit, use-dependent blockade. A much smaller number of ion channel therapeutics have been developed, which target an auxiliary subunit. The most compelling of these interact with the $\alpha_{2} \delta$ subunit of $\mathrm{Ca}_{\mathrm{V}} 2.2$ and are marketed therapies for the treatment of multiple CNS indications.

Gabapentin, 1-(aminomethyl)cyclohexaneacetic acid (Neurontin, Pfizer), was originally developed as a chemical analogue of GABA (compounds 22 and 23, Figure 8) to reduce the spinal reflex for the treatment of spasticity and was found to have anticonvulsant activity in various animal models of seizure (Taylor et al, 1998). In addition, it also displays efficacy in a number of animal models of inflammatory and neuropathic pain (Hunter et al, 1997; Kaneko et al, 2000; Shimoyama et al, 1997). Clinically, gabapentin is indicated as an add-on medication for the treatment of partial seizures and a variety of neuropathic pain syndromes, such as postherpetic neuralgia (Curran and Wagstaff, 2003; Plaghki et al, 2004). It is also claimed to have shown benefit in other clinical disorders such as fibromyalgia, anxiety, bipolar disorder, and hot flashes, although it has not been approved for these indications (Arnold et al, 2007; Cheng and Chiou, 2006). The possible mechanisms of action for gabapentin have been extensively studied and several hypotheses have been postulated (Cheng and Chiou, 2006; Taylor et al, 1998). Originally, it was thought that effects of gabapentin were mediated by its interaction with GABA receptors, however, despite early reports of an interaction with $\mathrm{GABA}_{\mathrm{B}}$ receptors in recombinant cell lines, Xenopus oocytes and rat brain slices, later imaging and pharmacological evaluations did not 


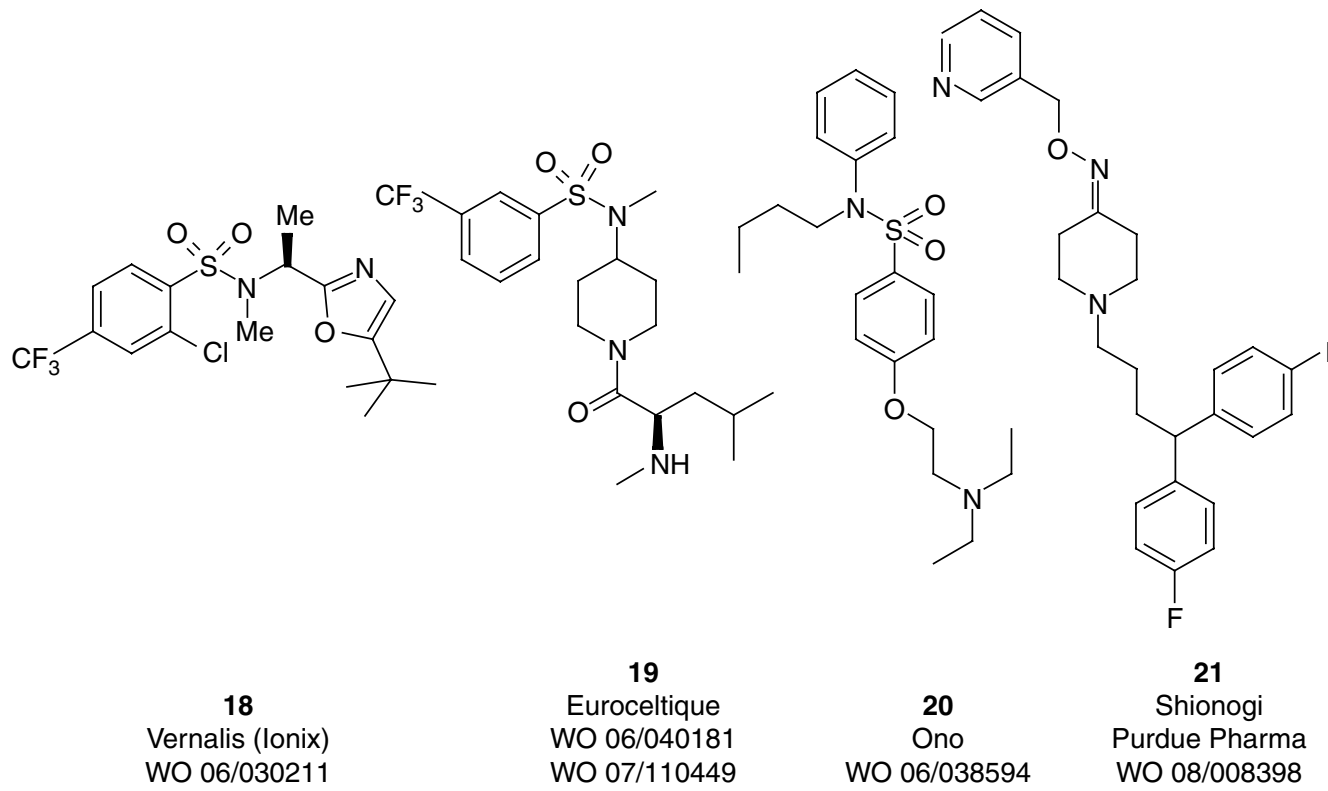

Figure 7. Examples of Cav2.2 antagonists from the patent literature (Benjamin et al, 2006; Chen et al, 2007; Hobbs et al, 2006; Matsumura et al, 2008; Ohtani et al, 2006).
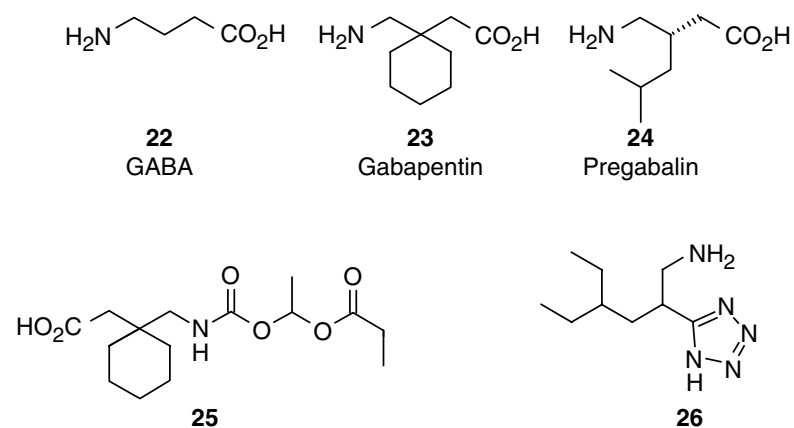

Prodrug of gabapentin Xenport - XP13512

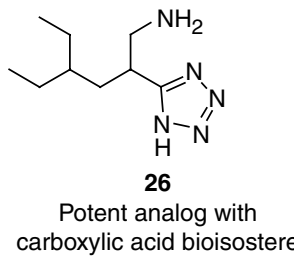

Figure 8. GABA, gabapentin, and analogs

support an interaction with either receptors or transporters of the GABA system (Bertrand et al, 2001; Cheng et al, 2004; Shimizu et al, 2004; Taylor et al, 2007).

A great deal of work was undertaken to isolate, validate, and characterize the binding site for gabapentin as the $\alpha_{2} \delta$ subunit of $\mathrm{Ca}_{\mathrm{V}} 2.2$. There are four variants of the $\alpha_{2} \delta$ subunit and gabapentin binds with high affinity to $\alpha_{2} \delta-1$ and $\alpha_{2} \delta-2$, which vary slightly in their distribution in the CNS (Wiser et al, 1996). For a number of years, the mechanism of how binding to this subunit resulted in analgesic effects through $\mathrm{Ca}_{\mathrm{V}} 2.2$ was elusive. Early reports indicated an inhibitory effect of gabapentin on calcium currents (Bayer et al, 2004; Rock et al, 1993; Sutton et al, 2002), but many subsequent studies were unable to replicate this work, perhaps because of the varied experimental conditions between laboratories, such as the subunit composition of the native calcium channels in different preparations. It is thought that the role of the $\alpha_{2} \delta$ subunit is in regulating the membrane insertion of the $\alpha_{1}$ subunit, as well as in modulating the voltage dependence and kinetic properties of channel gating. Very recently it has been shown that chronic application of gabapentin reduces plasma membrane expression of calcium channels in heterologous expression systems, suggesting that gabapentin, through its interaction with the $\alpha_{2} \delta$ subunit, causes a disruption of calcium channel trafficking (Hendrich et al, 2008).

Despite its widespread use in the clinic and a compelling safety profile (somnolence and dizziness most prevalently noted), gabapentin must be titrated to quite high levels (g/ day) to achieve efficacy and many patients experience suboptimal benefit, or in the case of pain management, little pain relief at all. However, following quickly on the heels of gabapentin was the approval of pregabalin (Lyrica), also brought to the clinic by Pfizer. Pregabalin (compound 24, Figure 8) has a sixfold higher binding affinity for $\alpha_{2} \delta$ than gabapentin and has been shown to have greater bioavailability (Gajraj, 2007; Taylor et al, 2007). In addition, pregabalin has been shown to reduce calcium influx at a number of nerve terminals, resulting in a decrease in the release of such neurotransmitters as glutamate, norepinephrine and substance $\mathrm{P}$, providing another possible means by which it exerts its effects clinically (Fehrenbacher et al, 2003). Pregabalin is currently approved in the United States as an adjunctive treatment for partial seizures and for the treatment of pain syndromes such as diabetic neuropathy, postherpetic neuralgia, and fibromyalgia, making it the first drug approved for more than one neuropathic pain condition (Crofford et al, 2005; Dworkin et al, 2003; Lesser et al, 2004; Rosenstock et al, 2004). 
Additional indications have been approved in Europe, including the use of pregabalin in anxiety disorders (Sabatowski et al, 2004).

Although many groups have worked towards the development of more efficacious analogues of gabapentin, in general these efforts have been plagued by the poor bioavailability of simple amino acid based derivatives. Pregabalin not only binds $\alpha_{2} \delta$, but is also a substrate for active transport, believed to enter into the CNS by the system L amino-acid transporter (Su et al, 1995, 2005). To improve bioavailability without relying on an active transport mechanism, acid bioisosteres (a substituent or group that imparts similar biological properties to a chemical compound, but enhances the physical properties for drug development) and prodrugs have been employed (Field et al, 2007). (Comprehensive review of the development of drug-like ligands for $\alpha_{2} \delta$.) The prodrug XP13512 (compound 25, Figure 8) has been shown to improve exposure in two different species compared to dosing gabapentin itself. XP13512 has been demonstrated to increase plasma levels of gabapentin by 9-fold in the monkey and by 17 -fold in the rat following oral administration, and 34-fold in the monkey following direct intracolonic administration compared to gabapentin by the same route (Cundy et al, 2004). Compound 26 (Figure 8) is an example of a compound with a tetrazole as a carboxylic acid bioisostere, which was shown to have potent binding to $\alpha_{2} \delta$ and demonstrated robust anticonvulsant activity in vivo. Although there is still a great deal to understand about the mechanisms within which an interaction with the $\alpha_{2} \delta$ subunit can alter calcium channel function, the targeting of auxiliary subunits is a compelling area to explore for the development of novel therapeutics.

\section{Ligand-Gated Ion Channels: Subtype-Selective Modulation of $\mathrm{GABA}_{\mathrm{A}}$ in Drug Development}

GABA is the major inhibitory neurotransmitter in the mammalian CNS and mediates fast inhibitory synaptic interactions by the $\mathrm{GABA}_{\mathrm{A}}$ receptor. Binding of GABA to $\mathrm{GABA}_{\mathrm{A}}$, localized on postsynaptic membranes, results in a conformational change in the ion channel, allowing the flow of chloride ions into the cell. This causes hyperpolarization of the membrane potential and inhibition of neuronal activity.

The $\mathrm{GABA}_{\mathrm{A}}$ receptor belongs to a family of pentameric ligand-gated ion channels that also includes nicotinic acetylcholine, strychnine-sensitive glycine, and serotonin 3 $\left(5 \mathrm{HT}_{3}\right)$ receptors (Le Novere and Changeux, 2001). Sixteen different subunits can be components of the $\mathrm{GABA}_{\mathrm{A}}$ channel, $\alpha(1-6), \beta(1-3), \gamma(1-3), \delta, \varepsilon, \pi$, and $\theta$ (Barnard et al, 1998; Whiting, 2003). Five subunits are arranged around a central pore that makes up the actual ion channel (Figure 9). Each subunit has a large extracellular N-terminal domain, which incorporates part of the agonist-/antagonistbinding site, followed by three membrane-spanning domains (TM1-TM3), an intracellular loop of variable length and a fourth membrane-spanning domain (TM4) with the $\mathrm{C}$-terminal end being extracellular. The second membranespanning domain (TM2) forms the wall of the channel pore. $\mathrm{GABA}_{\mathrm{A}}$ receptors are generally comprised two $\alpha$-, two $\beta$ and one $\gamma$-subunit (McKernan and Whiting, 1996; Whiting, 2003).

The $\mathrm{GABA}_{\mathrm{A}}$ receptor contains distinct-binding sites for many pharmacologically active compounds, including anesthetics, anticonvulsants, anxiolytics, and sedative-hypnotics. GABA binds to the extracellular $\mathrm{N}$-terminal domain of each $\alpha$-subunit, near the interface between the $\alpha$ - and
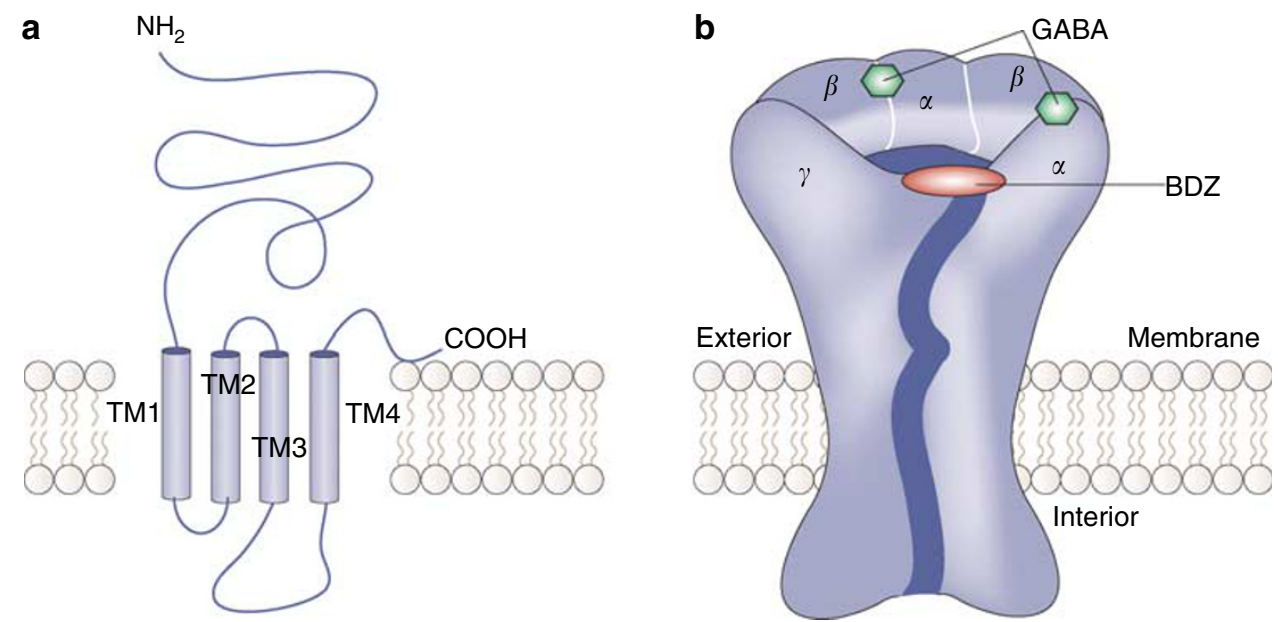

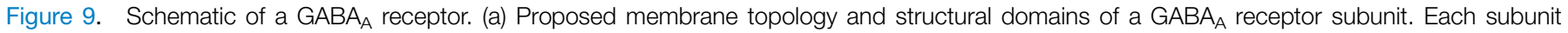
contains a large extracellular agonist-/antagonist-binding N-terminal domain, four transmembrane domains and a large cytoplasmic loop between M3 and M4. The second membrane-spanning domain (M2) forms the wall of the channel pore. (b) Vertical cross section showing the pentameric arrangement of subunits $(2 \alpha, 2 \beta$, and $1 \gamma)$ necessary to create the central chloride permeable channel. The recognition sites for GABA are indicated at the interface between the $\alpha$ - and $\beta$-subunits, and for the benzodiazepines at the interface between $\alpha$ - and $\gamma$-subunits. 
$\beta$-subunits. Most pharmacologically active compounds do not interact directly with the GABA-binding site, but act as allosteric modulators, either reducing or enhancing the actions of GABA at its receptor. These include such drugs as the synthetic steroid anesthetic, alphaxalone, a positive allosteric modulator of GABA activity, which interacts with $\delta$-subunit-containing $\mathrm{GABA}_{\mathrm{A}}$ receptors, and the loop diuretic, furosemide, which interacts with $\alpha_{6}$ subunitcontaining $\mathrm{GABA}_{\mathrm{A}}$ receptors to allosterically decrease GABA activity. In addition to distinct-binding sites for neuroactive steroids and furosemide, $\mathrm{GABA}_{\mathrm{A}}$ receptors contain binding sites for picrotoxin, sedative-hypnotic barbiturates, ethanol, inhalation anesthetics, and a number of divalent cations. The most extensively studied of the allosteric modulators of GABA on $\mathrm{GABA}_{\mathrm{A}}$ receptors are the benzodiazepines (Johnston, 1996), typified by the compounds diazepam (Valium ${ }^{\circledR}$ ) and alprazolam (Xanax ${ }^{\circledR}$; compounds 27 and 28, Figure 10), and widely prescribed for the treatment of anxiety disorders for many decades.

Benzodiazepines bind the $\mathrm{GABA}_{\mathrm{A}}$ receptor at a site situated at the interface between the $\alpha$ - and $\gamma$-subunits (Benson et al, 1998; Minier and Sigel, 2004). Although benzodiazepines are highly efficacious compounds, their use is limited by significant side effects, which can include sedation, amnesia, tolerance, dependence, and withdrawal (Buffett-Jerrott and Stewart, 2002; Shader and Greenblatt, 1993; Woods, 1998). These effects are believed to be mediated by their specific interactions with the $\mathrm{GABA}_{\mathrm{A}}$ receptor. Benzodiazepines have been shown to bind to and potentiate GABA activity at $\mathrm{GABA}_{\mathrm{A}}$ receptors containing $\alpha_{1}, \alpha_{2}, \alpha_{3}$, or $\alpha_{5}$ combined with $\beta \gamma$-subunits, but not those combinations containing $\alpha_{4}$ or $\alpha_{6}$ (Benson et al, 1998; Rudolph et al, 1999). A specific point mutation in the $\alpha$-subunits has been identified as conferring this selectivity and several transgenic mouse lines have been generated to further explore the role of these subunits in the actions of benzodiazepines. Studies utilizing these transgenic mice have provided evidence for the role of receptors containing the $\alpha_{1}$ subunit in mediating the sedative effects of diazepam, receptors containing the $\alpha_{2}$ subunit in mediating the anxiolytic effects of diazepam and receptors containing the $\alpha_{5}$ subunit in mediating both the effects of diazepam on memory functions and on tolerance to the sedative effects of the drug (Collinson et al, 2002; Low et al, 2000; McKernan et al, 2000; Reynolds et al, 2001).

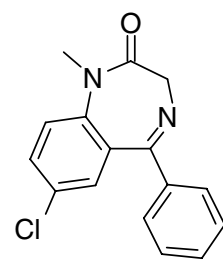

27

Diazepam<smiles>COCc1c(C(=O)OC(C)C)ncc2[nH]c3ccc(OCc4ccccc4)cc3c12</smiles>

30

Abecarnil

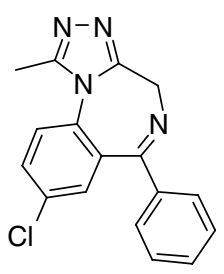

28

Alprazolam

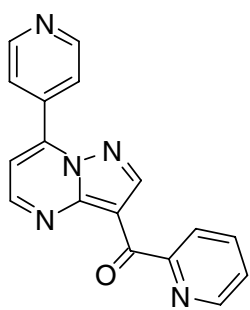

31

Ocinaplon<smiles>CC(C)(C)OC(=O)c1ncn2c1[C@H]1CCCN1C(=O)c1c(Br)cccc1-2</smiles>

29

Bretazenil

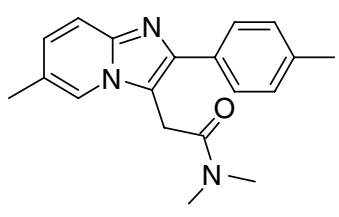

32

Zolpidem<smiles>CCN(C(C)=O)c1cccc(-c2ccnc3c(C#N)cnn23)c1</smiles>

33

Zaleplon<smiles>CN1CCN(C(=O)O[C@H]2c3nccnc3C(=O)N2c2ccc(Cl)cn2)CC1</smiles>

34

Eszopiclone<smiles>CCn1ncnc1COc1nn2c(-c3cc(F)ccc3F)nnc2cc1C(C)(C)C</smiles>

35

L-838,417

Figure 10. Examples of $\mathrm{GABA}_{\mathrm{A}}$ modulators. 
With this knowledge in hand, drug discovery efforts aimed at providing a new and improved benzodiazepine have taken a number of paths. Some efforts have attempted to develop nonselective, partial agonists of the $\mathrm{GABA}_{\mathrm{A}}$ receptor, with the goal of producing efficacy with reduced side effect liability. Several compounds have progressed to the clinic, but whereas they have demonstrated anxiolytic efficacy in animal models with reduced effects on sedation, muscle relaxation, and withdrawal, these effects were not completely borne out in man, and these attempts were discontinued (Figure 10). Bretazenil (Roche; compound 29, Figure 10; Busto et al, 1994; van Steveninck et al, 1996) demonstrated clinical efficacy but was unable to show a separation between the anxiolytic benefit and the sedative liability. Abecarnil (Schering; compound 30, Figure 10; Dubinsky et al, 2002; Stephens et al, 1990), having demonstrated partial agonism in some animal models, was unable to demonstrate significant efficacy once in the clinic. Ocinaplon (DOV; compound 31, Figure 10; Lippa et al, 2005), was most promising for its benzodiazepine-like efficacy and absence of untoward side effects in man, however, was unfortunately discontinued because of enzyme elevations in liver function tests.

A second approach to a new generation of benzodiazepines has been undertaken with an attempt to synthesize compounds with selective affinity for different $G_{A B A}$ receptor subunits. This has proven to be successful in the development of novel therapeutics for the treatment of insomnia. The marketed drugs, zolpidem (Ambien ${ }^{\circledR}$, compound 32, Figure 10), zaleplon (Sonata ${ }^{\mathbb{R}}$; compound 33, Figure 10), and eszopiclone (Lunesta ${ }^{\circledR}$; compound 34, Figure 10) all have varying pharmacological profiles with respect to their interactions with $\mathrm{GABA}_{\mathrm{A}}$ subunits, but all of these compounds have a preferred affinity for the $\alpha_{1}$ subunit (Petroski et al, 2006; Sanna et al, 2002). Although these drugs have proven to be effective in preferentially targeting sedation by selective interaction with $\alpha_{1}$, when present in high concentrations, they retain the potential liabilities associated with the nonsubunit-selective classical benzodiazepines such as triazolam $\left(\right.$ Halcion ${ }^{\circledR}$ ). Similar attempts have been made to develop $\alpha_{2}$ - or $\alpha_{2 / 3}$-selective compounds for the treatment of anxiety. L-838,417 (Merck; compound 35, Figure 10; McKernan et al, 2000), a positive modulator of $\alpha_{2}, \alpha_{3}$, and $\alpha_{5}$, but a neutralizing modulator at $\alpha_{1}$ (no effect on GABA activity by $\alpha_{1}$ but able to block activity of allosteric modulators at this site), showed promising effects preclinically but was never seen to enter the clinic. Numerous other compounds have been described with somewhat selective profiles, but as yet, a clinically efficacious compound has not emerged from these efforts (Da Settimo et al, 2007; Johnston, 2005).

Given the complexity of the interaction of classical benzodiazepines with multiple subunit combinations of the $\mathrm{GABA}_{\mathrm{A}}$ receptor, it is not surprising that drug discovery efforts to find subtype-selective compounds has been undertaken, nor that the process to bring these efforts to fruition is a difficult one. The development of the $\alpha_{1-}$ - selective sedative/hypnotics however, provides evidence for the validity of this approach and the impetus for moving forward in these endeavors.

\section{Drug Development for Ion Channel Modulators: HTS Limitations}

A significant barrier to the development of successful ion channel modulators is the difficulty in evaluating the interaction of novel compounds with ion channel targets experimentally and in a manner by which drug discovery efforts can progress in a timely fashion. Traditional highthroughput methods, such as those that have proven successful for GPCR targets have not demonstrated the same promise. Establishment of stable cell lines for use in HTS has been hampered by the need to selectively choose and coexpress the preferred subunit combinations necessary to elicit proper ion channel function while maintaining cell survival. This has often been difficult, particularly with voltage-gated ion channel expression systems. In addition, because of the need to develop subtype-selective compounds, multiple cell lines, expressing ion channels that are closely related to the primary target, must be available for discrete assessment of channel selectivity. Historically, binding assays, whereby novel chemical entities are screened for their ability to displace a radiolabeled ligand specific to the site of interest on the channel have not proven to be reliable in predicting ion channel function (Denyer et al, 1998). In addition, by virtue of the novelty of the interactions that are being targeted, specific radioligands have been difficult to develop. High-throughput cellbased assays aimed at evaluating ion channel function have been somewhat more successful but are not without their limitations. The measurement of ion flux through the use of radiotracers is commonly employed in the study of potassium and sodium channels (Mattheakis and Savchenko, 2001; Parihar et al, 2003; Xu et al, 2001). This methodology provides a direct measure of channel function and a good correlation with electrophysiology but requires a high level of channel expression has poor temporal resolution and is quite costly. The measurement of changes in ion concentration using fluorescent detection methods is common for ions such as calcium where well-established indicators are available (eg Fura-2, Fluo-3, Fluo-4), but development of these assays for other ions has been hindered by the lack of selective and sensitive ion-specific indicators (Wolff et al, 2003). In these cases, specific dyes that are sensitive to changes in the membrane potential have been employed to provide an indirect measure of channel function. This methodology has seen the most utility, but delivers the most variable correlation with direct electrophysiological methods. In addition, in the case of voltage-gated channels, the mechanism by which the activation of the channel takes place is artificially induced by a toxin or a drug rather than an electrical impulse and a high degree of false positives/negatives can be anticipated. 
The gold standard for assessment of ion channel activity was introduced in the late 1970s by Neher and Sakmann (Hamill et al, 1981; Neher and Sakmann, 1976). The wholecell patch-clamp technique allows the direct recording of ion fluxes across single ion channels or cell membranes and has become the ultimate tool for studying ion channel properties. It provides a detailed set of data on ion channel function with incomparable time resolution (ms) and sensitivity (picoamperes). Unfortunately, the conventional manual patch-clamp technique is time-consuming, lowthroughput, and requires highly skilled electrophysiologists, rendering it unsuitable for large-scale high-throughput drug discovery. Recent advances however, have been made in the development of medium throughput patch-clamp systems, allowing for automation of the technique (Farre et al, 2007; Wood et al, 2004). Some of these systems include PatchXpress $^{\mathrm{TM}}$ from Axon Instruments, IonWorks $\mathrm{HT}^{\mathrm{TM}}$ from Molecular Devices and QPatch ${ }^{\mathrm{TM}}$ from Sophion Bioscience. The advent of these technologies holds promise for a path forward for higher throughput ion channel drug discovery for the pharmaceutical industry in the future.

\section{DRUG DISCOVERY CHALLENGES OF THE FUTURE}

There are many hurdles on the road to the discovery and development of potential therapeutics to treat human disease, not the least of which is the fundamental understanding of the target related to a disease state and the drugability of this target, making it amenable to interaction with novel small molecule therapeutics. Serendipity is important in the identification of most drugs on the market today. With the elucidation of the human genome and the promise of selectively specifying molecular targets for various disease states, future efforts are relying more and more on technology-driven initiatives to identify specific molecular interactions that can provide the efficacy required in the disease whereas minimizing potential liabilities. For example, initiatives such as the Molecular Library Screening Center Network, part of the NIH roadmap for Medical Research, provides funding for the discovery of methods that can identify small molecules through novel interactions for which selective small molecule probes are not currently available. These will ideally help in the validation of targets that can play a modulatory or reversal role in the disease. This provides the necessary emphasis on understanding the true drugability of a target and less on the serendipitous findings of currently available random screening processes.

Recent reports expanding the notion of receptor dimerization across different GPCR classes represents a new and increasingly complex dimension to drug discovery. For example, utilizing state-of-the-art techniques the recent description of heterodimer formation between the serotonin $5-\mathrm{HT}_{2 \mathrm{~A}}$ (class A) receptor and the mGluR2 (class C) receptor and this dimer is involved in psychosis (Gonza-
lez-Maeso et al, 2008) is evidence that 'drugability' of targets need not be restricted to single molecular entities with a nice well-defined pocket that can be chemically targeted. In fact multiple drug target opportunities exist in this situation ranging from the classic small molecules interacting within the same pocket as the endogenous ligands for these receptors, through allosteric interactions that target a conformational change in the receptor/protein, to the targeting of the molecular interaction of the dimer itself and the subsequent differential regulation of intracellular signaling mechanisms that this dimer generates (GonzalezMaeso et al, 2008). Finally, there is a wealth of emerging information from both the biological disciplines (bioinformatics, genomics, proteomics, and other -omics) and the chemistry of small molecule discovery that needs to be integrated and parallelized rather than continuing with the classic paradigm of 'synthesize-generate a data pointsynthesize again' that is still in effect for drug discovery. The understanding of biological variables such as homoand heterodimerization, alternative splicing, state-dependent conformations, posttranslational modifications, and disease-dependent gene and protein expression offer a myriad of exciting opportunities for the discovery and development of novel therapeutics.

\section{ACKNOWLEDGEMENTS}

We acknowledge the expert assistance of Miss Charlotte Cartwright for the illustrations in this paper.

\section{DISCLOSURE/CONFLICT OF INTEREST}

All authors declare that they are full time employees and as a result, shareholders of Neurocrine Biosciences Inc., a biopharmaceutical company focused on neurological and endocrine diseases and disorders. Further information is available through the Company's website: www.neurocrine. com.

\section{REFERENCES}

Adams CL, Lawrence AJ (2007). CGP7930: a positive allosteric modulator of the GABAB receptor. CNS Drug Rev 13: 308-316.

Arikkath J, Campbell KP (2003). Auxiliary subunits: essential components of the voltage-gated calcium channel complex. Curr Opin Neurobiol 13: 298-307.

Arnold LM, Goldenberg DL, Stanford SB, Lalonde JK, Sandhu HS, Keck PE et al (2007). Gabapentin in the treatment of fibromyalgia: a double blind, placebo controlled multicenter trial. Arthritis Rheum 56: 1336-1344.

Arvanitis AG, Gilligan PJ, Chorvat RJ, Cheeseman RS, Christos TE, Bakthavatchalam $R$ et al (1999). Non-peptide corticotropin-releasing hormone antagonists: syntheses and structure-activity relationships of 2-anilinopyrimidines and triazines. J Med Chem 42: 805-818.

Atanassoff PG, Hartmannsgruber MW, Thrasher J, Wermeling D, Longton W, Gaeta $R$ et al (2000). Ziconotide, a new N-type calcium channel blocker, administered intrathecally for acute postoperative pain. Reg Anesth Pain Med 25: 274-278.

Bale TL, Vale WW (2004). CRF and CRF receptors: role in stress responsivity and other behaviors. Annu Rev Pharmacol Toxicol 44: 525-557.

Ballesteros JA, Shi L, Javitch JA (2001). Structural mimicry in G protein-coupled receptors: implications of the high-resolution structure of rhodopsin for structure-function analysis of rhodopsin-like receptors. Mol Pharmacol 60: $1-19$. 
Barnard EA, Skolnick P, Olsen RW, Mohler H, Sieghart W, Biggio G et al (1998). International Union of Pharmacology. XV. Subtypes of gamma-aminobutyric acidA receptors: classification on the basis of subunit structure and receptor function. Pharmacol Rev 50: 291-313.

Bayer K, Ahmadi S, Zeilhofer HU (2004). Gabapentin may inhibit synaptic transmission in the mouse spinal cord dorsal horn through a preferential block of P/Q-type $\mathrm{Ca}^{2+}$ channels. Neuropharmacology 46: 743-749.

Bean BP (1989). Neurotransmitter inhibition of neuronal calcium currents by changes in channel voltage dependence. Nature 340: 153-156.

Benjamin ER, Chen Z, Sha D, Tafesse L, Victory SF, Whitehead JWF et al (2006). Piperidinyl compounds and their preparation, pharmaceutical compositions, and use as $\mathrm{N}$-type calcium channel modulators or blockers for treatment or prevention of pain. WO 2006040181: 150 pp.

Benson JA, Low K, Keist R, Mohler H, Rudolph U (1998). Pharmacology of recombinant gamma-aminobutyric acidA receptors rendered diazepam-insensitive by point-mutated alpha-subunits. FEBS Lett 431: 400-404.

Bertolino M, Llinas RR (1992). The central role of voltage-activated and receptoroperated calcium channels in neuronal cells. Annu Rev Pharmacol Toxicol 32 399-421.

Bertrand S, Ng GY, Purisai MG, Wolfe SE, Severidt MW, Nouel D et al (2001). The anticonvulsant, antihyperalgesic agent gabapentin is an agonist at brain gammaaminobutyric acid type B receptors negatively coupled to voltage-dependent calcium channels. J Pharmacol Exp Ther 298: 15-24.

Bettler B, Kaupmann K, Mosbacher J, Gassmann M (2004). Molecular structure and physiological functions of $\operatorname{GABA}(\mathrm{B})$. receptors. Physiol Rev 84: 835-867.

Bezanilla F (2002). Voltage sensor movements. J Gen Physiol 120: 465-473.

Binet V, Brajon C, Le Corre L, Acher F, Pin JP, Prezeau L (2004). The heptahelical domain of GABA(B2) is activated directly by CGP7930, a positive allosteric modulator of the GABA(B) receptor. J Biol Chem 279: 29085-29091.

Binneman B, Feltner D, Kolluri S, Shi Y, Qiu R, Stiger T (2008). A 6-week randomized, placebo-controlled trial of $\mathrm{CP}-316,311$ (a selective $\mathrm{CRH} 1$ antagonist) in the treatment of major depression. Am J Psychiatry 165: 617-620.

Birch PJ, Dekker LV, James IF, Southan A, Cronk D (2004). Strategies to identify ion channel modulators: current and novel approaches to target neuropathic pain. Drug Discov Today 9: 410-418.

Birdsall NJ, Cohen F, Lazareno S, Matsui H (1995). Allosteric regulation of Gprotein-linked receptors. Biochem Soc Trans 23: 108-111.

Bondensgaard K, Ankersen M, Thogersen H, Hansen BS, Wulff BS, Bywater RP (2004). Recognition of privileged structures by G-protein coupled receptors J Med Chem 47: 888-899.

Bowersox SS, Gadbois T, Singh T, Pettus M, Wang YX, Luther RR (1996). Selective $\mathrm{N}$-type neuronal voltage-sensitive calcium channel blocker, SNX-111, produces spinal antinociception in rat models of acute, persistent and neuropathic pain. J Pharmacol Exp Ther 279: 1243-1249.

Brose WG, Gutlove DP, Luther RR, Bowersox SS, McGuire D (1997). Use of intrathecal SNX-111, a novel, N-type, voltage-sensitive, calcium channel blocker, in the management of intractable brachial plexus avulsion pain. Clin J Pain 13 256-259.

Buffett-Jerrott SE, Stewart SH (2002). Cognitive and sedative effects of benzodiazepine use. Curr Pharm Des 8: 45-58.

Busto U, Kaplan HL, Zawertailo L, Sellers EM (1994). Pharmacologic effects and abuse liability of bretazenil, diazepam, and alprazolam in humans. Clin Pharmacol Ther 55: 451-463.

Catterall WA (2000). Structure and regulation of voltage-gated $\mathrm{Ca}^{2+}$ channels. Annu Rev Cell Dev Biol 16: 521-555.

Chen C, Dagnino Jr R., De Souza EB, Grigoriadis DE, Huang CQ, Kim KI et al (1996). Design and synthesis of a series of non-peptide high-affinity human corticotropin-releasing factor1 receptor antagonists. J Med Chem 39 4358-4360.

Chen C, Pontillo J, Fleck BA, Gao Y, Wen J, Tran JA et al (2004a). 4-\{(2R)-[3Aminopropionylamido]-3-(2,4-dichlorophenyl)propionyl $\}-1-\{2-[(2-\quad$ thienyl)ethylaminomethyl]phenyl\}piperazine as a potent and selective melanocortin-4 receptor antagonist-design, synthesis, and characterization. J Med Chem 47 6821-6830.

Chen C, Wilcoxen KM, Huang CQ, Xie YF, McCarthy JR, Webb TR et al (2004b). Design of 2,5-dimethyl-3-(6-dimethyl-4-methylpyridin-3-yl)-7-dipropylaminopyrazolo[1,5-a]pyrimidine (NBI 30775/R121919) and structure-activity relationships of a series of potent and orally active corticotropin-releasing factor receptor antagonists. J Med Chem 47: 4787-4798.

Chen Z, Islam K, Shao B, Yao J, Zhou X, Kyle DJ (2007). Preparation of azetidinyl, pyrrolidinyl, piperidinyl, and hexahydroazepinyl benzenesulfonamides as $\mathrm{N}$-type calcium channel blockers. WO 2007110449: 235 pp.

Cheng JK, Chiou LC (2006). Mechanisms of the antinociceptive action of gabapentin. J Pharmacol Sci 100: 471-486
Cheng JK, Lee SZ, Yang JR, Wang CH, Liao YY, Chen CC et al (2004). Does gabapentin act as an agonist at native GABA(B) receptors? J Biomed Sci 11 346-355.

Christopoulos A (2002). Allosteric binding sites on cell-surface receptors: novel targets for drug discovery. Nat Rev Drug Discov 1: 198-210.

Cizkova D, Marsala J, Lukacova N, Marsala M, Jergova S, Orendacova J et al (2002). Localization of $\mathrm{N}$-type $\mathrm{Ca}^{2+}$ channels in the rat spinal cord following chronic constrictive nerve injury. Exp Brain Res 147: 456-463.

Collinson N, Kuenzi FM, Jarolimek W, Maubach KA, Cothliff R, Sur C et al (2002). Enhanced learning and memory and altered GABAergic synaptic transmission in mice lacking the alpha 5 subunit of the GABAA receptor. I Neurosci 22: 5572-5580.

Consortium IHGS (2004). Finishing the euchromatic sequence of the human genome. Nature 431: 931-945.

Crofford LJ, Rowbotham MC, Mease PJ, Russel IJ, Dworkin RH, Corbin AE et al (2005). Pregabalin for the treatment of fibromyalgia syndrome: results of a double blind placebo-controlled trial. Arthritis Rheum 52: 1264-1273.

Cundy KC, Annamalai T, Bu L, De Vera J, Estrela J, Luo W et al (2004). XP13512 [(+/-)-1-([(alpha-isobutanoyloxyethoxy)carbonyl]aminomethyl-1-cyclohexane acetic acid], a novel gabapentin prodrug: II. Improved oral bioavailability, dose proportionality and colonic absorption compared with gabapentin in rats and Monkeys. J Pharmacol Exp Ther 311: 324-333.

Curran MP, Wagstaff AJ (2003). Gabapentin: in postherpetic neuralgia. CNS Drugs 17: 975-982

Da Settimo F, Taliani S, Trincavelli ML, Montali M, Martini C (2007). GABA A/Bz receptor subtypes as targets for selective drugs. Curr Med Chem 14: 2680-2701.

Dautzenberg FM, Wille S, Lohmann R, Spiess J (1998). Mapping of the ligandselective domain of the Xenopus laevis corticotropin-releasing factor receptor 1 implications for the ligand-binding site. Proc Natl Acad Sci USA 95: 4941-4946.

Denyer J, Worley J, Cox B, Allenby G, Banks M (1998). HTS approaches to voltage gated ion channel drug discovery. Drug Discov Today 3: 323-332.

Dolphin AC (2003). Beta subunits of voltage-gated calcium channels. J Bioenerg Biomembr 35: 599-620.

Dong M, Pinon DI, Asmann YW, Miller LJ (2006). Possible endogenous agonist mechanism for the activation of secretin family $\mathrm{G}$ protein-coupled receptors. $\mathrm{Mo}$ Pharmacol 70: 206-213.

Drake MT, Violin JD, Whalen EJ, Wisler JW, Shenoy SK, Lefkowitz RJ (2008). Betaarrestin-biased agonism at the beta2-adrenergic receptor. J Biol Chem 283 5669-5676.

Dubinsky B, Vaidya AH, Rosenthal DI, Hochman C, Crooke JJ, DeLuca S et al (2002). 5-Ethoxymethyl-7-fluoro-3-oxo-1,2,3,5-tetrahydrobenzo[4,5]imidazo[1,2a]pyr idine-4- $N$-(2-fluorophenyl)carboxamide (RWJ-51204), a new nonbenzodiazepine anxiolytic. J Pharmacol Exp Ther 303: 777-790.

Dunlap K, Luebke Jl, Turner TJ (1995). Exocytotic $\mathrm{Ca}^{2+}$ channels in mammalian central neurons. Trends Neurosci 18: 89-98.

Dworkin RH, Corbin AE, Young Jr JP, Sharma U, LaMoreaux L, Bockbrader $\mathrm{H}$ et al (2003). Pregabalin for the treatment of postherpetic neuralgia: a randomized, placebo-controlled trial. Neurology 60: 1274-1283.

Ellinor PT, Zhang JF, Horne WA, Tsien RW (1994). Structural determinants of the blockade of $\mathrm{N}$-type calcium channels by a peptide neurotoxin. Nature 372 272-275

Farre C, Stoelzle S, Haarmann C, George M, Bruggemann A, Fertig N (2007). Automated ion channel screening: patch clamping made easy. Expert Opin Ther Targets 11: 557-565

Fehrenbacher JC, Taylor CP, Vasko MR (2003). Pregabalin and gabapentin reduce release of substance $P$ and CGRP from rat spinal tissues only after inflammation or activation of protein kinase C. Pain 105: 133-141.

Feng ZP, Doering CJ, Winkfein RJ, Beedle AM, Spafford JD, Zamponi GW (2003). Determinants of inhibition of transiently expressed voltage-gated calcium channels by omega-conotoxins GVIA and MVIIA. J Biol Chem 278: 20171-20178.

Field MJ, Li Z, Schwarz JB (2007). $\mathrm{Ca}^{2+}$ channel alpha2-delta ligands for the treatment of neuropathic pain. J Med Chem 50: 2569-2575.

Foord SM, Jupe S, Holbrook J (2002). Bioinformatics and type II G-protein-coupled receptors. Biochem Soc Trans 30: 473-479.

Gajraj NM (2007). Pregabalin: its pharmacology and use in pain management Anesth Analg 105: 1805-1815.

Gonzalez-Maeso J, Ang RL, Yuen T, Chan P, Weisstaub NV, Lopez-Gimenez JF et al (2008). Identification of a serotonin/glutamate receptor complex implicated in psychosis. Nature 452: 93-97.

Goudet C, Gaven F, Kniazeff J, Vol C, Liu J, Cohen-Gonsaud M et al (2004). Heptahelical domain of metabotropic glutamate receptor 5 behaves like rhodopsin-like receptors. Proc Natl Acad Sci USA 101: 378-383.

Grace CR, Perrin MH, DiGruccio MR, Miller CL, Rivier JE, Vale WW et al (2004). NMR structure and peptide hormone binding site of the first extracellula 
domain of a type B1 G protein-coupled receptor. Proc Natl Acad Sci USA 101: 12836-12841.

Grace CR, Perrin MH, Gulyas J, Digruccio MR, Cantle JP, Rivier JE et al (2007). Structure of the N-terminal domain of a type B1 G protein-coupled receptor in complex with a peptide ligand. Proc Natl Acad Sci USA 104: 4858-4863.

Grigoriadis DE (2005). The corticotropin-releasing factor receptor: a novel target for the treatment of depression and anxiety-related disorders. Expert Opin Ther Targets 9: 651-684.

Hamill OP, Marty A, Neher E, Sakmann B, Sigworth FJ (1981). Improved patchclamp techniques for high-resolution current recording from cells and cell-free membrane patches. Pflugers Arch 391: 85-100.

Harrington PE, Fotsch C (2007). Calcium sensing receptor activators: calcimimetics. Curr Med Chem 14: 3027-3034.

Hauger RL, Risbrough V, Brauns O, Dautzenberg FM (2006). Corticotropin releasing factor (CRF) receptor signaling in the central nervous system: new molecular targets. CNS Neurol Disord Drug Targets 5: 453-479.

Heinke B, Balzer E, Sandkuhler J (2004). Pre- and postsynaptic contributions of voltage-dependent $\mathrm{Ca}^{2+}$ channels to nociceptive transmission in rat spinal lamina I neurons. Eur J Neurosci 19: 103-111.

Hendrich J, Van Minh AT, Heblich F, Nieto-Rostro M, Watschinger K, Striessnig J et al (2008). Pharmacological disruption of calcium channel trafficking by the alpha2delta ligand gabapentin. Proc Natl Acad Sci USA 105: 3628-3633.

Heresco-Levy U (2005). Glutamatergic neurotransmission modulators as emerging new drugs for schizophrenia. Expert Opin Emerg Drugs 10: 827-844.

Hoare SR (2005). Mechanisms of peptide and nonpeptide ligand binding to Class B G-protein-coupled receptors. Drug Discov Today 10: 417-427.

Hoare SR, Brown BT, Santos MA, Malany S, Betz SF, Grigoriadis DE (2006). Single amino acid residue determinants of non-peptide antagonist binding to the corticotropin-releasing factor1 (CRF1) receptor. Biochem Pharmacol 72: 244-255.

Hoare SR, Fleck BA, Gross RS, Crowe PD, Williams JP, Grigoriadis DE (2008). Allosteric ligands for the corticotropin releasing factor type 1 receptor modulate conformational States involved in receptor activation. Mol Pharmacol 73: 1371-1380.

Hoare SR, Sullivan SK, Ling N, Crowe PD, Grigoriadis DE (2003). Mechanism of corticotropin-releasing factor type I receptor regulation by nonpeptide antagonists. Mol Pharmacol 63: 751-765.

Hoare SR, Sullivan SK, Schwarz DA, Ling N, Vale WW, Crowe PD et al (2004). Ligand affinity for amino-terminal and juxtamembrane domains of the corticotropin releasing factor type I receptor: regulation by G-protein and nonpeptide antagonists. Biochemistry 43: 3996-4011.

Hoare SRJ (2007). Allosteric modulators of class B G-protein-coupled receptors. Curr Neuropharmacol 5: 168-179.

Hobbs CJ, Lynch RM, Mellor SL, Radford F, Gilbert JC, Stokes S et al (2006). Preparation of acyclic sulfonamides as $\mathrm{N}$-type calcium channel antagonists. $W O$ 2006030211: $71 \mathrm{pp}$

Hodge CN, Aldrich PE, Wasserman ZR, Fernandez CH, Nemeth GA, Arvanitis A et al (1999). Corticotropin-releasing hormone receptor antagonists: framework design and synthesis guided by ligand conformational studies. J Med Chem 42 : 819-832.

Holsboer F (2003). High-quality antidepressant discovery by understanding stress hormone physiology. Ann N Y Acad Sci 1007: 394-404.

Hopkins AL, Groom CR (2002). The druggable genome. Nat Rev Drug Discov 1: 727-730.

Houamed KM, Kuijper JL, Gilbert TL, Haldeman BA, O'Hara PJ, Mulvihill ER et al (1991). Cloning, expression, and gene structure of a $G$ protein-coupled glutamate receptor from rat brain. Science 252: 1318-1321.

Hunter JC, Gogas KR, Hedley LR, Jacobson LO, Kassotakis L, Thompson J et al (1997). The effect of novel anti-epileptic drugs in rat experimental models of acute and chronic pain. Eur J Pharmacol 324: 153-160.

Ising M, Zimmermann US, Kunzel HE, Uhr M, Foster AC, Learned-Coughlin SM et al (2007). High-affinity CRF1 receptor antagonist NBI-34041: preclinical and clinical data suggest safety and efficacy in attenuating elevated stress response. Neuropsychopharmacology 32: 1941-1949.

Johnson MP, Baez M, Jagdmann Jr GE., Britton TC, Large TH, Callagaro DO et al (2003). Discovery of allosteric potentiators for the metabotropic glutamate 2 receptor: synthesis and subtype selectivity of $\mathrm{N}$-(4-(2-methoxyphenoxy)phenyl)$\mathrm{N}-(2,2,2-\quad$ trifluoroethylsulfonyl)pyrid-3-ylmethylamine. J Med Chem 46: 3189-3192.

Johnston GA (1996). GABAA receptor pharmacology. Pharmacol Ther 69: 173-198.

Johnston GA (2005). GABA(A) receptor channel pharmacology. Curr Pharm Des 11: 1867-1885.

Kaneko M, Mestre C, Sanchez EH, Hammond DL (2000). Intrathecally administered gabapentin inhibits formalin-evoked nociception and the expression of Fos-like immunoreactivity in the spinal cord of the rat. J Pharmacol Exp Ther 292 743-751.

Kang MG, Chen CC, Felix R, Letts VA, Frankel WN, Mori $Y$ et al (2001). Biochemical and biophysical evidence for gamma 2 subunit association with neuronal voltage-activated $\mathrm{Ca}^{2+}$ channels. J Biol Chem 276: 3291732924.

Kaupmann K, Huggel K, Heid J, Flor PJ, Bischoff S, Mickel SJ et al (1997). Expression cloning of $\mathrm{GABA}(\mathrm{B})$ receptors uncovers similarity to metabotropic glutamate receptors. Nature 386: 239-246.

Kaupmann K, Malitschek B, Schuler V, Heid J, Froestl W, Beck P et al (1998). GABA(B)-receptor subtypes assemble into functional heteromeric complexes. Nature 396: 683-687.

Kehne J, De Lombaert S (2002). Non-peptidic CRF1 receptor antagonists for the treatment of anxiety, depression and stress disorders. Curr Drug Target CNS Neurol Disord 1: 467-493.

Kunishima N, Shimada Y, Tsuji Y, Sato T, Yamamoto M, Kumasaka T et al (2000). Structural basis of glutamate recognition by a dimeric metabotropic glutamate receptor. Nature 407: 971-977.

Lander ES, Linton LM, Birren B, Nusbaum C, Zody MC, Baldwin J et al (2001). Initial sequencing and analysis of the human genome. Nature 409 860-921.

Le Novere N, Changeux JP (2001). The Ligand Gated Ion Channel database: an example of a sequence database in neuroscience. Philos Trans $R$ Soc Lond B: Biol Sci 356: 1121-1130.

Lesser H, Sharma U, LaMoreaux L, Poole RM (2004). Pregabalin relieves symptoms of painful diabetic neuropathy: a randomized controlled trial. Neurology 63: 2104-2110.

Liaw CW, Grigoriadis DE, Lorang MT, De Souza EB, Maki RA (1997a). Localization of agonist- and antagonist-binding domains of human corticotropin-releasing factor receptors. Mol Endocrinol 11: 2048-2053.

Liaw CW, Grigoriadis DE, Lovenberg TW, De Souza EB, Maki RA (1997b). Localization of ligand-binding domains of human corticotropinreleasing factor receptor: a chimeric receptor approach. Mol Endocrinol 11 980-985.

Lippa A, Czobor P, Stark J, Beer B, Kostakis E, Gravielle M et al (2005). Selective anxiolysis produced by ocinaplon, a $\operatorname{GABA}(\mathrm{A})$ receptor modulator. Proc Natl Acad Sci USA 102: 7380-7385.

Low K, Crestani F, Keist R, Benke D, Brunig I, Benson JA et al (2000). Molecular and neuronal substrate for the selective attenuation of anxiety. Science 290: $131-134$

Luo ZD, Calcutt NA, Higuera ES, Valder CR, Song YH, Svensson Cl et al (2002). Injury type-specific calcium channel alpha 2 delta-1 subunit up-regulation in rat neuropathic pain models correlates with antiallodynic effects of gabapentin. J Pharmacol Exp Ther 303: 1199-1205.

Markman JD, Dworkin RH (2006). Ion channel targets and treatment efficacy in neuropathic pain. J Pain 7(1 Suppl 1): S38-S47.

Masu M, Tanabe Y, Tsuchida K, Shigemoto R, Nakanishi S (1991). Sequence and expression of a metabotropic glutamate receptor. Nature 349: 760-765.

Matsumura A, Mikamiyama H, Tsuno N, Kyle DJ, Shao B, Yao J (2008). Preparation of oxime compounds as blockers of calcium channels useful in the treatment of pain. WO 2008008398: $599 \mathrm{pp}$.

Mattheakis LC, Savchenko A (2001). Assay technologies for screening ion channel targets. Curr Opin Drug Discov Devel 4: 124-134

McGivern JG (2006). Targeting N-type and T-type calcium channels for the treatment of pain. Drug Discov Today 11: 245-253.

McGivern JG (2007). Ziconitide: a review of its pharmacology and use in the treatment of pain. Neuropsychiatr Dis Treat 3: 69-85.

McKernan RM, Rosahl TW, Reynolds DS, Sur C, Wafford KA, Atack JR et al (2000). Sedative but not anxiolytic properties of benzodiazepines are mediated by the GABA(A) receptor alpha1 subtype. Nat Neurosci 3: 587-592.

McKernan RM, Whiting PJ (1996). Which GABAA-receptor subtypes really occur in the brain? Trends Neurosci 19: 139-143.

Mesleh MF, Shirley WA, Heise CE, Ling N, Maki RA, Laura RP (2007). NMR structural characterization of a minimal peptide antagonist bound to the extracellular domain of the corticotropin-releasing factor1 receptor. $\mathrm{J}$ Biol Chem 282: 6338-6346.

Miljanich GP (2004). Ziconotide: neuronal calcium channel blocker for treating severe chronic pain. Curr Med Chem 11: 3029-3040.

Minier F, Sigel E (2004). Techniques: use of concatenated subunits for the study of ligand-gated ion channels. Trends Pharmacol Sci 25: 499-503.

Neher E, Sakmann B (1976). Single-channel currents recorded from membrane of denervated frog muscle fibres. Nature 260: 799-802.

Ng GY, Clark J, Coulombe N, Ethier N, Hebert TE, Sullivan R et al (1999). Identification of a GABAB receptor subunit, gb2, required for functional GABAB receptor activity. J Biol Chem 274: 7607-7610. 
Nielsen SM, Nielsen LZ, Hjorth SA, Perrin MH, Vale WW (2000). Constitutive activation of tethered-peptide/corticotropin-releasing factor receptor chimeras. Proc Natl Acad Sci USA 97: 10277-10281.

Niswender CM, Jones CK, Conn PJ (2005). New therapeutic frontiers for metabotropic glutamate receptors. Curr Top Med Chem 5: 847-857.

Ohtani T, Kambe T, Kobayashi K, Takimizu H, Ito Y (2006). Preparation of benzenesulfonamide compounds as $\mathrm{N}$-type calcium channel inhibitors. WO 2006038594: 196 pp.

Olivera BM, Miljanich GP, Ramachandran J, Adams ME (1994). Calcium channel diversity and neurotransmitter release: the omega-conotoxins and omegaagatoxins. Annu Rev Biochem 63: 823-867.

Pajouhesh H, Ding Y, Pajouhesh H, Holland R, Hum G (2008). Preparation of diarylmethyl piperidines as calcium channel blockers. WO 2008031227: 104 pp.

Parihar AS, Groebe DR, Scott VE, Feng J, Zhang XF, Warrior U et al (2003). Functional analysis of large conductance $\mathrm{Ca} 2(+)$-activated $\mathrm{K}(+)$ channels: ion flux studies by atomic absorption spectrometry. Assay Drug Dev Technol 1: 647-654

Parmentier ML, Prezeau L, Bockaert J, Pin JP (2002). A model for the functioning of family 3 GPCRs. Trends Pharmacol Sci 23: 268-274.

Penn RD, Paice JA (2000). Adverse effects associated with the intrathecal administration of ziconotide. Pain 85: 291-296.

Perrin MH, Sutton S, Bain DL, Berggren WT, Vale WW (1998). The first extracellular domain of corticotropin releasing factor-R1 contains major binding determinants for urocortin and astressin. Endocrinology 139: 566-570.

Petroski RE, Pomeroy JE, Das R, Bowman H, Yang W, Chen AP et al (2006). Indiplon is a high-affinity positive allosteric modulator with selectivity for alpha1 subunit-containing GABAA receptors. J Pharmacol Exp Ther 317: 369-377.

Pin JP, Kniazeff J, Liu J, Binet V, Goudet C, Rondard P et al (2005). Allosteric functioning of dimeric class C G-protein-coupled receptors. FEBS J 272: 29472955.

Plaghki L, Adriaensen H, Morlion B, Lossignol D, Devulder J (2004). Systematic overview of the pharmacological management of postherpetic neuralgia. An evaluation of the clinical value of critically selected drug treatments based on efficacy and safety outcomes from randomized controlled studies. Dermatology 208: 206-216.

Rasmussen SG, Choi HJ, Rosenbaum DM, Kobilka TS, Thian FS, Edwards PC et al (2007). Crystal structure of the human beta(2) adrenergic G-protein-coupled receptor. Nature 450: 383-387.

Reynolds DS, McKernan RM, Dawson GR (2001). Anxiolytic-like action of diazepam: which GABA(A) receptor subtype is involved? Trends Pharmacol Sci 22: 402-403.

Rock DM, Kelly KM, Macdonald RL (1993). Gabapentin actions on ligand- and voltage-gated responses in cultured rodent neurons. Epilepsy Res 16: 89-98.

Rosenstock J, Tuchman M, LaMoreaux L, Sharma U (2004). Pregabalin for the treatment of painful diabetic peripheral neuropathy: a double-blind, placebocontrolled trial. Pain 110: 628-638.

Rudd MT, McCauley JA (2005). Positive allosteric modulators of the metabotropic glutamate receptor subtype 2 (mGluR2). Curr Top Med Chem 5: 869-884.

Rudolph U, Crestani F, Benke D, Brunig I, Benson JA, Fritschy JM et al (1999). Benzodiazepine actions mediated by specific gamma-aminobutyric acid(A) receptor subtypes. Nature 401: 796-800.

Sabatowski R, Galvez R, Cherry DA, Jacquot F, Vincent E, Maisonobe P et al (2004). Pregabalin reduces pain and improves sleep and mood disturbances in patients with post-herpetic neuralgia: results of a randomised, placebocontrolled clinical trial. Pain 109: 26-35

Sabido-David C, Faravelli L, Salvati P (2004). The therapeutic potential of $\mathrm{Na}^{+}$and $\mathrm{Ca}^{2+}$ channel blockers in pain management. Expert Opin Investig Drugs 13: 1249-1261.

Sanna E, Busonero F, Talani G, Carta M, Massa F, Peis M et al (2002). Comparison of the effects of zaleplon, zolpidem, and triazolam at various GABA(A) receptor subtypes. Eur J Pharmacol 451: 103-110.

Schroeder Cl, Doering CJ, Zamponi GW, Lewis RJ (2006). N-type calcium channel blockers: novel therapeutics for the treatment of pain. Med Chem 2: 535-543.

Schulz DW, Mansbach RS, Sprouse J, Braselton JP, Collins J, Corman M et al (1996). CP-154,526: a potent and selective nonpeptide antagonist of corticotropin releasing factor receptors. Proc Natl Acad Sci USA 93: 10477-10482.

Sebhat IK, Martin WJ, Ye Z, Barakat K, Mosley RT, Johnston DB et al (2002). Design and pharmacology of $N$-[(3R)-1,2,3,4-tetrahydroisoquinolinium-3-ylcarbonyl]$(1 R)$-1-(4-chlorobenzyl)-2-[4-cyclohexyl-4-(1H-1,2,4-triazol-1-ylmethyl)piperidin1-yl]-2-oxoethylamine (1), a potent, selective, melanocortin subtype-4 receptor agonist. J Med Chem 45: 4589-4593.

Shader RI, Greenblatt DJ (1993). Use of benzodiazepines in anxiety disorders. N Engl J Med 328: 1398-1405.

Shimizu S, Honda M, Tanabe M, Ono H (2004). GABAB receptors do not mediate the inhibitory actions of gabapentin on the spinal reflex in rats. J Pharmacol Sci 96: 444-449.
Shimoyama N, Shimoyama M, Davis AM, Inturrisi CE, Elliott KJ (1997). Spina gabapentin is antinociceptive in the rat formalin test. Neurosci Lett 222: 65-67.

Smagin GN, Dunn AJ (2000). The role of CRF receptor subtypes in stress-induced behavioural responses. Eur J Pharmacol 405: 199-206.

Snutch TP (2003). Novel N-type calcium channel blockers. 226th ACS National MeetingNew York, NY, September 7-11.

Snutch TP, Fisher DM (2007). Method for increasing the bioavailability of benzhydryl piperazine containing compounds by oral administration with food. WO 2007133481: 30 pp.

Staats PS, Yearwood T, Charapata SG, Presley RW, Wallace MS, Byas-Smith M et al (2004). Intrathecal ziconotide in the treatment of refractory pain in patients with cancer or AIDS: a randomized controlled trial. JAMA 291: 63-70.

Stephens DN, Schneider HH, Kehr W, Andrews JS, Rettig KJ, Turski L et al (1990). Abecarnil, a metabolically stable, anxioselective beta-carboline acting at benzodiazepine receptors. J Pharmacol Exp Ther 253: 334-343.

Su TZ, Feng MR, Weber ML (2005). Mediation of highly concentrative uptake of pregabalin by L-type amino acid transport in Chinese hamster ovary and Caco-2 cells. J Pharmacol Exp Ther 313: 1406-1415.

Su TZ, Lunney E, Campbell G, Oxender DL (1995). Transport of gabapentin, a gamma-amino acid drug, by system I alpha-amino acid transporters: a comparative study in astrocytes, synaptosomes, and $\mathrm{CHO}$ cells. J Neurochem 64: 2125-2131.

Sun H, Greeley DN, Chu XJ, Cheung A, Danho W, Swistok J et al (2004). A predictive pharmacophore model of human melanocortin-4 receptor as derived from the solution structures of cyclic peptides. Bioorg Med Chem 12 2671-2677.

Sutton KG, Martin DJ, Pinnock RD, Lee K, Scott RH (2002). Gabapentin inhibits high-threshold calcium channel currents in cultured rat dorsal root ganglion neurones. Br J Pharmacol 135: 257-265.

Taylor CP, Angelotti T, Fauman E (2007). Pharmacology and mechanism of action of pregabalin: the calcium channel alpha2-delta (alpha2-delta) subunit as a target for antiepileptic drug discovery. Epilepsy Res 73: 137-150.

Taylor CP, Gee NS, Su TZ, Kocsis JD, Welty DF, Brown JP et al (1998). A summary of mechanistic hypotheses of gabapentin pharmacology. Epilepsy Res 29 233-249

Tellew JE, Luo Z (2008). Small molecule antagonists of the corticotropin releasing factor (CRF) receptor: recent medicinal chemistry developments. Curr Top Med Chem 8: 506-520.

Todorovic A, Haskell-Luevano C (2005). A review of melanocortin receptor small molecule ligands. Peptides 26: 2026-2036.

Tsuchiya D, Kunishima N, Kamiya N, Jingami H, Morikawa K (2002). Structural views of the ligand-binding cores of a metabotropic glutamate receptor complexed with an antagonist and both glutamate and Gd3+. Proc Natl Acad Sci USA 99: 2660-2665.

van Steveninck AL, Gieschke R, Schoemaker RC, Roncari G, Tuk B, Pieters MS et al (1996). Pharmacokinetic and pharmacodynamic interactions of bretazenil and diazepam with alcohol. Br J Clin Pharmacol 41: 565-573.

Venter JC, Adams MD, Myers EW, Li PW, Mural RJ, Sutton GG et al (2001). The sequence of the human genome. Science 291: 1304-1351.

Wang YX, Pettus M, Gao D, Phillips C, Scott Bowersox S (2000). Effects of intrathecal administration of ziconotide, a selective neuronal $\mathrm{N}$-type calcium channel blocker, on mechanical allodynia and heat hyperalgesia in a rat model of postoperative pain. Pain 84: 151-158.

Webster EL, Lewis DB, Torpy DJ, Zachman EK, Rice KC, Chrousos GP (1996). In vivo and in vitro characterization of antalarmin, a nonpeptide corticotropin-releasing hormone $(\mathrm{CRH})$ receptor antagonist: suppression of pituitary $\mathrm{ACTH}$ release and peripheral inflammation. Endocrinology 137: 5747-5750.

Westenbroek RE, Hoskins L, Catterall WA (1998). Localization of $\mathrm{Ca}^{2+}$ channe subtypes on rat spinal motor neurons, interneurons, and nerve terminals. J Neurosci 18: 6319-6330.

White JH, Wise A, Main MJ, Green A, Fraser NJ, Disney GH et al (1998). Heterodimerization is required for the formation of a functional $\mathrm{GABA}(\mathrm{B})$ receptor. Nature 396: 679-682

Whiting PJ (2003). GABA-A receptor subtypes in the brain: a paradigm for CNS drug discovery? Drug Discov Today 8: 445-450.

Winquist RJ, Pan JQ, Gribkoff VK (2005). Use-dependent blockade of Cav2.2 voltage-gated calcium channels for neuropathic pain. Biochem Pharmacol 70: 489-499.

Wiser O, Trus M, Tobi D, Halevi S, Giladi E, Atlas D (1996). The alpha 2/delta subunit of voltage sensitive $\mathrm{Ca}^{2+}$ channels is a single transmembrane extracellular protein which is involved in regulated secretion. FEBS Lett 379: 15-20.

Wolff C, Fuks B, Chatelain P (2003). Comparative study of membrane potentialsensitive fluorescent probes and their use in ion channel screening assays. J Biomol Screen 8: 533-543. 
Wood C, Williams C, Waldron GJ (2004). Patch clamping by numbers. Drug Discov Today 9: 434-441.

Woods JH (1998). Problems and opportunities in regulation of benzodiazepines. J Clin Pharmacol 38: 773-782.

Xu J, Wang X, Ensign B, Li M, Wu L, Guia A et al (2001). Ion-channel assay technologies: quo vadis? Drug Discov Today 6: 1278-1287.

Yang J, Ellinor PT, Sather WA, Zhang JF, Tsien RW (1993). Molecular determinants of $\mathrm{Ca}^{2+}$ selectivity and ion permeation in L-type $\mathrm{Ca}^{2+}$ channels. Nature 366: 158-161.

Yogeeswari P, Ragavendran JV, Sriram D (2007). Neuropathic pain: strategies in drug discovery and treatment. Expert Opin Drug Discov 2: 169-184.
Yu FH, Yarov-Yarovoy V, Gutman GA, Catterall WA (2005). Overview of molecular relationships in the voltage-gated ion channel superfamily. Pharmacol Rev 57 387-395.

Zhorov BS, Tikhonov DB (2004). Potassium, sodium, calcium and glutamategated channels: pore architecture and ligand action. I Neurochem 88 782-799.

Zobel AW, Nickel T, Kunzel HE, Ackl N, Sonntag A, Ising M et al (2000). Effects of the high-affinity corticotropin-releasing hormone receptor 1 antagonist R121919 in major depression: the first 20 patients treated. J Psychiatr Res $\mathbf{3 4}$ $171-181$ 